\title{
A "Rua-Pátio" e a Caracterização dos Espaços Livres de Edificação das Novas Vilas Paulistanas
}

Solange Aragão

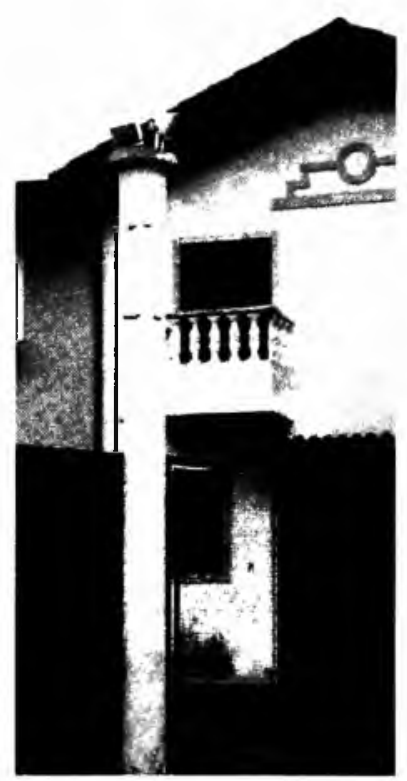

Arquiteta e mestre em arquitetura e urbanismo (FAUUSP) 
A composição dos espaços livres de edificação das novas vilas paulistanas difere, sob certos aspectos, daquela encontrada nas vilas de antigamente. Por outro lado, percebe-se que, a todo momento, tenta-se resgatar caracteristicas e usos dos antigos conjuntos de residências construidos no interior dos quarteirões.

Se as vilas do início e de meados do século, especialmente as projetadas para dar abrigo à classe média, possuiam sempre uma rua estreita que conduzia a um pátio de uso comum aos moradores das casas de fachada usualmente estreitas que o circundavam ou ladeavam, nas vilas construidas a partir dos anos 90 , a rua estreita e o pátio são substituidos por um único espaço, o qual estamos denominando "rua-pátio". Esse espaço é, na verdade, uma rua ligeiramente larga, que se pretende seja também um pátio - ou tenha a função do pátio das vilas de outros tempos, próprio ao lazer e à sociabilidade. Nisto, na presença de elementos como fontes e luminárias e, por vezes, na própria arquitetura, vê-se claramente a tentativa de se resgatar, talvez, a idéia do que foram as primeiras vilas paulistanas idéia esta que, não raro, aparece mesclada à de outras vilas (européias ou norte-americanas).

O que se propõe aqui é a definição do que vem a ser a "rua-pátio" e a caracterização dos espaços livres de edificação das novas vilas paulistanas, que apresentam certas inovações em relação às mais antigas e, ao mesmo tempo, mantêm-se fiéis a soluções empregadas tradicionalmente.

The open spaces of the newest villas of São Paulo differ, in some aspects, from those of the oldest ones. On the other hand, architects and constructors are always trying to bring back some characteristics and uses of the villas built in this city in the past.

While the villas of the beginning and the middle of the 20th century used to have a narrow street that led to a courtyard surrounded by the houses, the villas of the 90 s have one larger street with some characteristics of a courtyard. Therefore, we call it a "courtyard street".

Some elements - such as fountains and lampposts -, which supposedly remind people of the oldest villas, are located in this open space - that it is intended to be a social space.

We aim here to define the "courtyard street" and to analyse the open spaces of the newest villas of São Paulo and their uses.

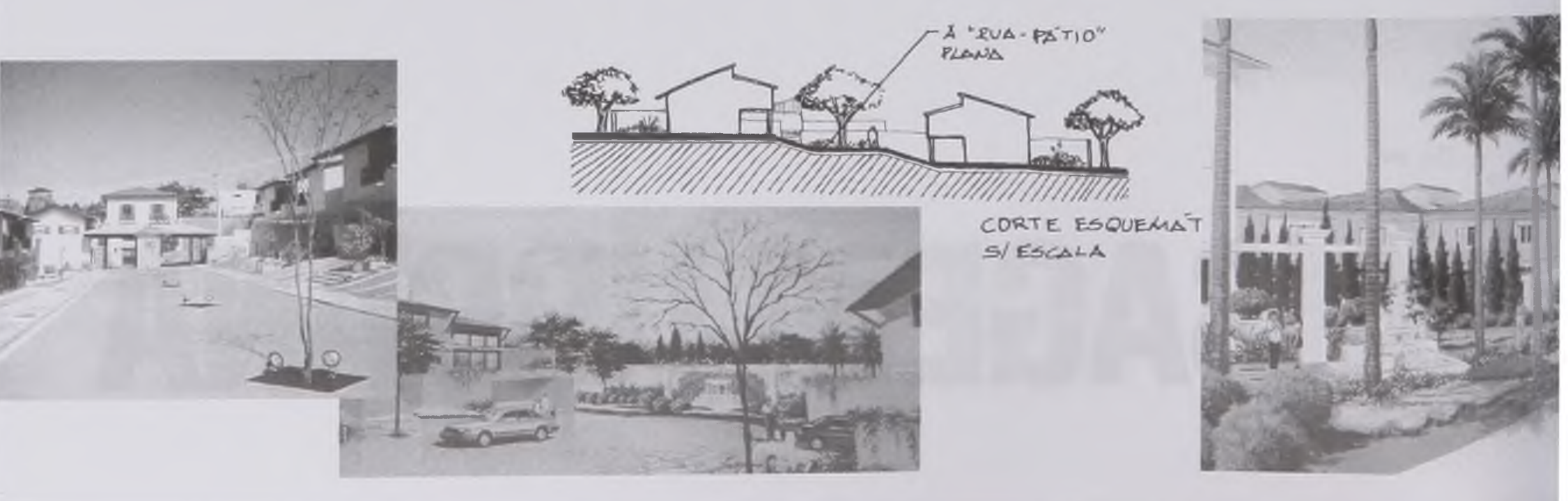




\section{A "Rua-Pátio" e a Caracterização dos Espaços Livres de Edificação das Novas Vilas Paulistanas}

Praça, rua e pátio são três palavras que definem espaços livres de edificação cercados ou ladeados por edifícios e muros, construções. Espaços usualmente descobertos, com uma árvore aqui e ali ou vegetação exuberante, com um ou outro elemento a exercer as mais diversas funçōes, como luminárias ou postes de iluminação, talvez uma pequena fonte. Mas enquanto a praça é, por definição, um "lugar público" ${ }^{1}$ o pátio tende a possibilitar uma utilização mais restrita, possui um número menor de usuários - em certos casos tem caráter semipúblico; em outros, privado. Já a rua, a não ser que esteja isolada, de alguma forma, da cidade, é também de domínio público, lugar de todos ${ }^{2}$

A praça, a rua e o pátio podem ser entendidos como locais de encontro e de sociabilidade la rua de outrora, não a atual, dos automóveis e transeuntes apressados). Contudo, a rua é um caminho que conduz a uma determinada localidade, uma "passagem" entre os blocos de edificação; tem a função de "ligar" pontos distantes, outros caminhos, outras passagens. A praça e o pátio são lugares de reunião, de um encontro mais demorado, antes espaços de estar e de lazer que de passagem.

Se nas vilas de antigamente (destinadas à classe média e construídas no interior dos quarteirões) os espaços não-edificados eram compostos por ruas estreitas que se abriam em pátios, para os quais davam as portas e janelas das residências nas novas vilas, essa conjunção da rua estreita com o pátio se transforma na "rua-pátio" A rua estreita, agora relativamente larga, é projetada com o intento de assumir a função do pátio. Não deixa de ser rua, uma vez que garante o acesso dos moradores e seus automóveis às residências (é um espaço de circulação, que faz a ligação entre a entrada da vila e cada uma das unidades que a compõem). Mas, sendo um "pedaço de rua", delimitado pelos muros e portões do conjunto, assemelha-se a um pátio, normalmente arborizado e, de certa forma, recluso. Representa, também, uma área de transição entre as casas (espaço privado) e a rua externa, pública. Possui fontes, jardins e luminárias.

(1) A definição de praça como "lugar público" consta no dicionário de Aurélio Buarque de Holanda: "Lugar público cercado de edifícios; largo.' (p.1124).

No livro Cidade brasileira, do Prof. Dr. Murillo Marx. lemos: "Logradouro público por excelência, a praça deve sua existência, sobretudo, aos adros de nossas igrejas.' (p. 50).

(2) Em sua obra Liçōes de arquitetura, o arquiteto e professor Herman Hertzberger coloca o seguinte: "Se as casas são domínios privados, a rua é o domínio público.' (p. 64). 
Alguns arquitetos, ao projetar os espaços livres das novas vilas, têm a idéia da "grande praça" Embora a palavra "praça" em sua origem grega plateia significasse "rua larga" esse espaço, um tanto quanto amplo, entre edificações, não pode ser chamado praça, porquanto não seja "lugar público" Seu uso é restrito aos moradores e o acesso não é permitido a estranhos. As novas vilas são condomínios fechados.

Além da "rua-pátio", parte dos novos conjuntos possui certos equipamentos como playground, piscinas, churrasqueira, salas de ginástica e quadras esportivas - equipamentos esses bastante comuns nas áreas comunitárias dos edifícios de apartamentos. Se acentuam o aspecto de condomínio das vilas erguidas recentemente, ocasionam uma diminuição do uso da "ruapátio" concentrando adultos e crianças em um ou outro ponto. Estas, ao invés de brincarem na "rua-pátio" ficam no playground; ao invés de jogarem bola no espaço entre as residências, vão para as quadras. Da mesma forma, os adultos que poderiam trocar idéias nesse espaço, conversam na sala de ginástica. Assim, a "rua-pátio" imaginada como um lugar de múltiplos usos, transforma-se num lugar deserto.

É preciso se considerar também que as famílias que adquirem casas nesses condomínios almejam uma privacidade maior que os moradores das antigas vilas.

Nestas, os espaços livres eram mais utilizados devido, entre outros fatores, às menores dimensões das residências. O pátio era uma extensão da casa.

Dentre os fatores que determinam a caracterização dos espaços livres das novas vilas (bem como das antigas), sendo quase sempre o espaço principal a "rua-pátio" estão: a implantação das residências, as características do relevo, as dimensões do terreno, o estilo arquitetônico e o projeto paisagístico. E é justamente pela análise desses fatores que pretendemos caracterizar os espaços não-edificados dos conjuntos construídos nos últimos anos na capital paulista.

\section{Da Conjunção da rua estreita com o pátio À "Rua-Pátio"}

"Uma alameda central larga e arborizada resgata o clima e as brincadeiras das vilas de antigamente - e a segurança é garantida por equipamentos de última geração. O paisagismo percorre todo o condomínio e invaide as unidades, contribuindo para fazer do Los Álamos um lugar onde é gostoso viver. "Catálogo Imobiliário do Los Álamos Condomínio.

Nas vilas de interior de quarteirão, construídas no início ou em meados do século 20 , principalmente aquelas destinadas à camada média da classe média, era muito comum a existência de uma rua estreita (extensa ou não), que conduzia ao pátio. Este podia ser apenas

(3) Mais uma vez, recorremos ao dicionário de Aurélio Buarque de Holanda: "Do gr. plateia (subentendendo-se hodos), 'rua larga'; pelo lat. platea."

$204 \begin{aligned} & \text { Paisagem } \\ & \text { Ambiente } \\ & \text { Ensaios } \\ & 13\end{aligned}$

São Paulo n. 13 p. 201229 dez. 2000 

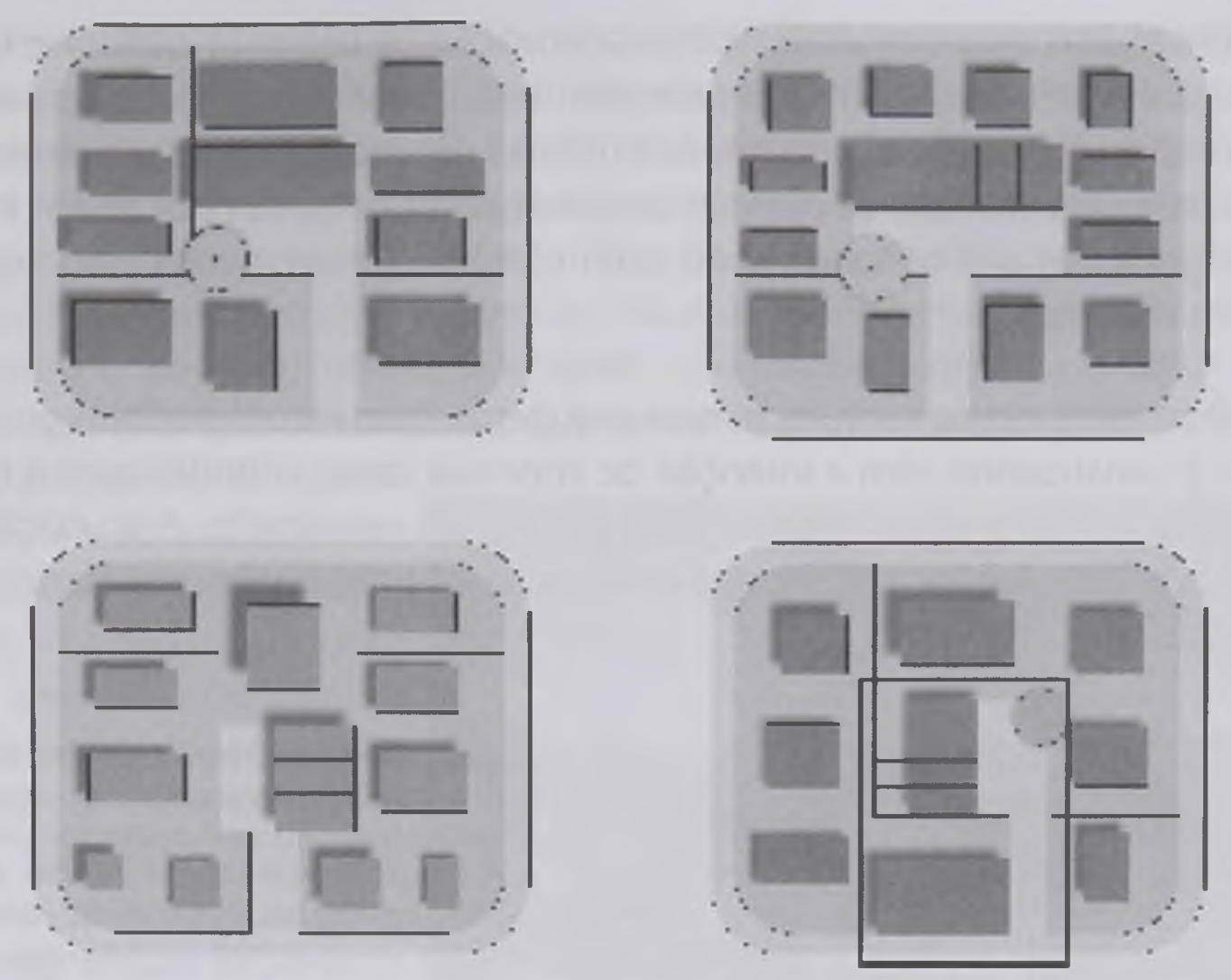

Figura 1: O terreno escolhido para construção das antigas vilas ficava no interior das quadras. Assim, a rua estreita se tornava necessária para garantir o acesso às residências - e ao pátio, de forma variada. Quando o terreno tinha frente para a rua principal, o construtor implantava casas maiores nesta faixa (voltada para a rual e deixava o terreno restante para as casas da vila propriamente dita.

uma continuação dessa rua, formar com ela um "L" ou um "T", ser simplesmente um "corredor desencontrado" ou ter forma variada. Isto acontecia porque o terreno adquirido para construção dessas vilas, de custo inferior, ficava, muitas vezes, no interior do quarteirão ${ }^{4}$ e, para fazer a ligação com a rua principal, era necessária a rua estreita.

Quando o terreno tinha frente para a rua, o construtor fazia erguer, nessa faixa, alguns sobrados geminados, com dimensões um pouco maiores, pelos quais poderiam ser cobrados aluguéis mais elevados (já que o ideal de moradia urbana era a casa com frente para a rua principal). 0 terreno restante, na parte interna da quadra, ficava reservado, então, à vila propriamente dita. E mais uma vez a rua estreita se tornava imprescindível para garantir o acesso ao conjunto.

(4) A idéia de vila nesses tempos estava ligada à idéia de um conjunto de residências que poderia ser construido com gastos reduzidos. Assim, o terreno escolhido era de custo inferior (situado no interior da quadra, quando o ideal de moradia urbana era a casa com frente para a rua principal), as casas eram geminadas, visando, tanto a economia de materiais construtivos (com as paredes comuns) como a construção do maior número possível de unidades residenciais, e estava sempre presente uma certa racionalidade do espaço. 
Nas vilas construídas recentemente lapós a aprovação da Lei n. 11.605, que tornou viável sua construçãol, o terreno, com raras exceções, tem frente para a rua principal. Todavia, o ideal de moradia urbana deixou de ser, nas últimas décadas, a casa com frente para a rua; hoje, um número significativo de pessoas procura casas protegidas por muros e portões que possibilitem também um certo convívio com vizinhos "selecionados", ou seja, casas em condomínios fechados.

Assim, ao idealizar os novos conjuntos, nem arquitetos, nem incorporadores ou proprietários de terrenos e construtores têm a intenção de construir casas voltadas para a rua principal, posto que as casas "escondidas" e protegidas são as mais valorizadas. A ocupação do terreno se dá, portanto, de maneira diferenciada em relação às antigas vilas, resultando numa nova estrutura espacial.

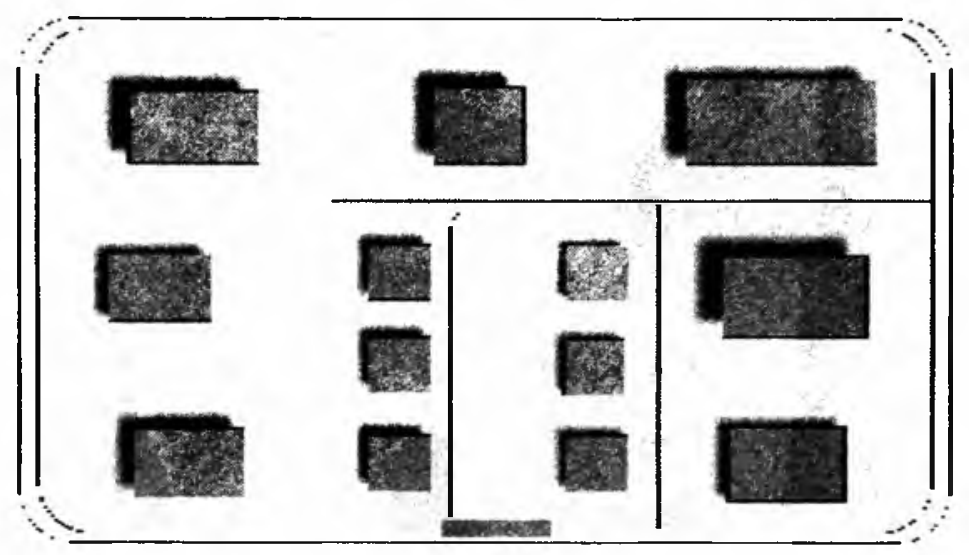

Figura 2: Nas novas vilas, o terreno tem frente para a rua. No entanto, hoje, as casas mais valorizadas são aquelas protegidas por muros $e$ portöes, no interior do condomínio. Como não são construídas casas com frente para a rua principal, a rua estreita e o pátio dão lugar à "rua-pátio" nos novos conjuntos.

Em primeiro lugar, a área limítrofe é toda murada, possuindo portões de acesso e guarita na entrada. As unidades residenciais são dispostas nessa região - intramuros - e, entre elas, criase um espaço que não é nem bem uma rua, nem bem um pátio, e que, tampouco, pode ser considerado uma praça. É, na verdade, uma rua com características de pátio ou um pátio com características de rua (ou de praça), que algumas vezes possui canteiros de vegetação, outras vezes possui pequenos jardins, e, em alguns casos, árvores alinhadas. Luminárias e fontes também se fazem notar com certa freqüência.

A "rua-pátio", esse espaço entre edificações nas novas vilas, embora quase sempre linear, assume aspectos diferenciados em cada conjunto. Nas vilas modernas ou com características modernas, as árvores esparsas (predomina o piso sobre a vegetação) aparecem dispostas em linha reta ou são plantadas em frente às residências. Há, certamente, um ou outro canteiro com alguma vegetação, e a fonte, quando aparece, expressa a modernidade do conjunto.

Os dois melhores exemplares de vilas "modernas" (dentre aquelas que tivemos a oportunidade de analisar) são o Los Álamos Condomínio e o Brooksville. O primeiro está implantado no Jardim Marajoara e o segundo está sendo construído no Brooklin. No Los Álamos, há uma fileira de árvores bem espaçadas no centro da "rua-pátio"; no Brooksville, a rua é orlada de arvoredos.

\begin{tabular}{l|lll} 
Paisagem & São Paulo n. 13 p. $201 \quad 229$ dez. 2000 \\
\cline { 2 - 3 } $\begin{array}{l}\text { Ambiente } \\
\text { Ensaios } \\
13\end{array}$ & & &
\end{tabular}


Nas vilas influenciadas pelo pós-moderno ou de cunho eclético, encontramos, nos espaços livres entre as construções, pórticos e fontes, pirâmides de vidro. No Ville de France, na rua Campo Verde, nas proximidades do Iguatemi, o autor do projeto quis passar o "conceito da grande praça". Como já vimos, esse espaço nāo pode ser considerado praça, posto que nāo é "lugar público" Talvez seja um "grande pátio" com ares de praça. Os canteiros são distribuídos à francesa, possuem mesmo um desenho francês. No eixo "monumental" diminuto, está locada a pirâmide de vidro. O piso é de mosaico português. Não existem bancos ou locais de estar. É um "grande pátio" com a função de realçar a arquitetura e de permitir o acesso às residências - não é convidativo ao lazer ou ao estar. A existência de um estacionamento comum no subsolo - sob o "pátio" tira, em parte, a função de rua desse espaço. As pessoas que moram nesse condomínio utilizam seus carros em grande parte das vezes que deixam suas casas. Havendo acesso a cada unidade pela garagem, talvez elas sequer atravessem o pátio costumeiramente, a não ser quando se dirigem para a sala de ginástica ou para o salão de jogos (pontos de convívio e de confluência). O "grande pátio" fica vazio, entre os blocos de edificação.

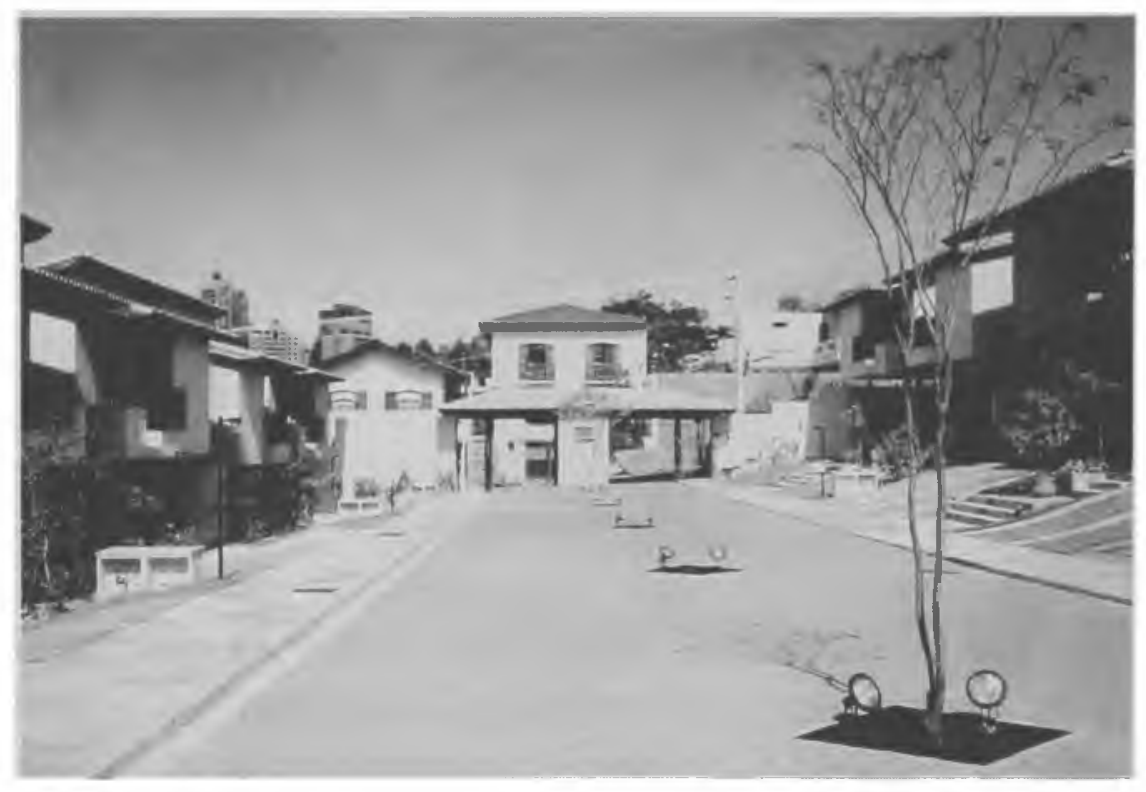

Foto 3: Los Álamos. Uma fileira de árvores no centro da "rua-pátio" Fonte: Foto da autora

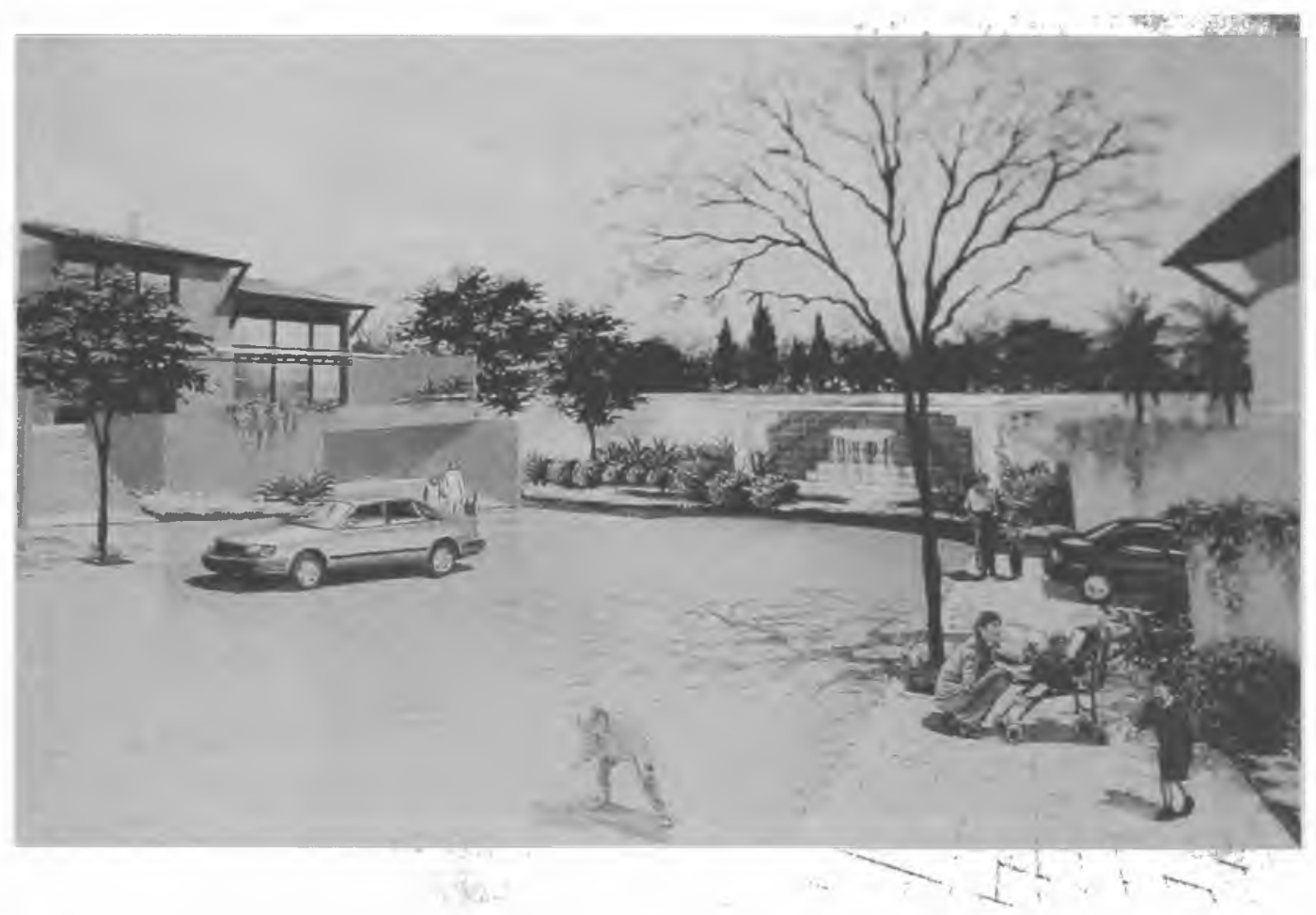

Foto 4: Brooksville. A rua ladeada de árvores de pequeno porte Fonte: Lopes Imobiliária (Perspectiva do Catálogo Imobiliário) /Darpan/Lopes 


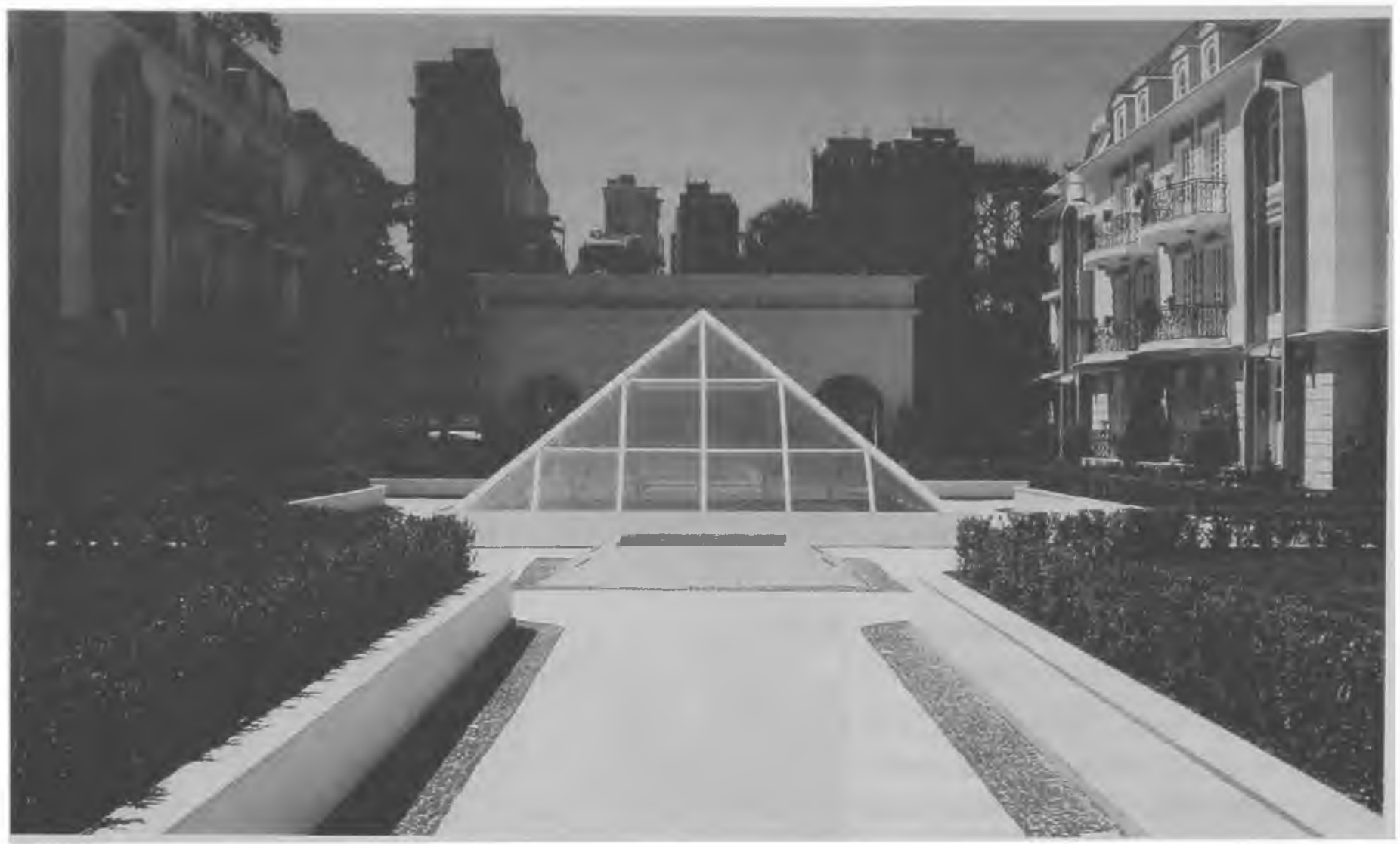

Foto 5: Ville de France. "O grande pátio"

Fonte: Foto da autora

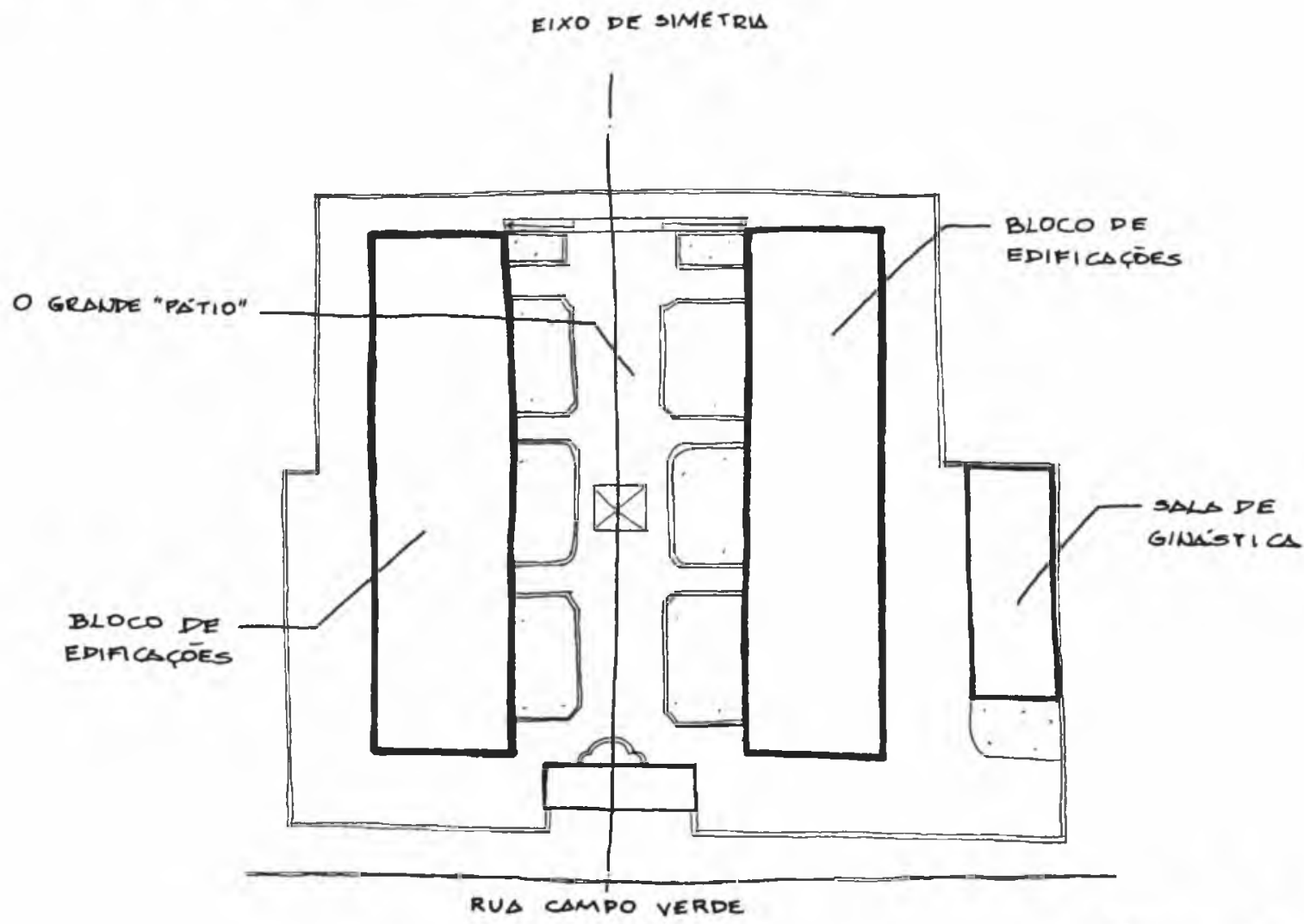

VILLE DE FRANCE IMPLANTAÇA

Figura 6: Ville de France (Implantação Esquemática) (ESQUEMA SI ESCALA) Fonte: Foto da autora 
No projeto dos espaços livres do Palmeiras Imperiais Private Houses - vila que será construída na rua Dr. Celso Dario Guimarães, pelas proximidades do Palácio do Governo - há pórticos e fontes no jardim. Esses elementos concedem à "rua-pátio" um certo tom de pós-modernidade, na linha das praças que seguem esse estilo.

Nos conjuntos maiores, destinados à classe média, com sobrados geminados, produzidos em série, pretendendo-se, de fato, um retorno nostálgico, é comum a locação de lampadários nos espaços livres da edificação. Existem ainda, neste caso, playgrounds para as crianças e vagas cobertas (ou nāo) para estacionamento de veículos. A "rua-pátio" nesses conjuntos assemelha-se muito a uma rua comum - talvez deixe mesmo de ter caráter de pátio. Asfaltada, é delimitada pela calçada, ou calçamento, onde estão distribuídos os lampadários ou luminárias, ou por um pequeno gramado em frente das residências, como acontece nas chamadas "Villas de São Francisco"

É nos conjuntos projetados para a classe média alta, implantados em bairros demasiadamente valorizados, cujos terrenos atingem preços exorbitantes, que a rua com caráter de pátio se faz notar com maior freqüência. No terreno não muito extenso, as casas são dispostas lado a lado, geminadas, isoladas ou agrupadas ao longo da rua - em alguns casos, existem residências ao fundo. Cada casa possui sua própria garagem e por toda a "rua-pátio" estão espalhados canteiros e pequenos jardins ou algumas árvores. São exemplos disso tanto as já citadas vilas com características modernas, como determinados conjuntos que apresentam em sua arquitetura um ou outro ornamento. O Giardino di Milano, na rua Marechal Deodoro, e o Sans Souci, na rua Joaquim Nabuco, no Brooklin, estão entre esses conjuntos. No primeiro, a rua é plana e as casas estão situadas em nível um pouco acima desse espaço de uso comum. No segundo, a declividade do terreno exigiu uma solução diferenciada. A "rua-pátio" é inclinada, descendo da entrada até as casas no fundo do terreno. A topografia foi respeitada.

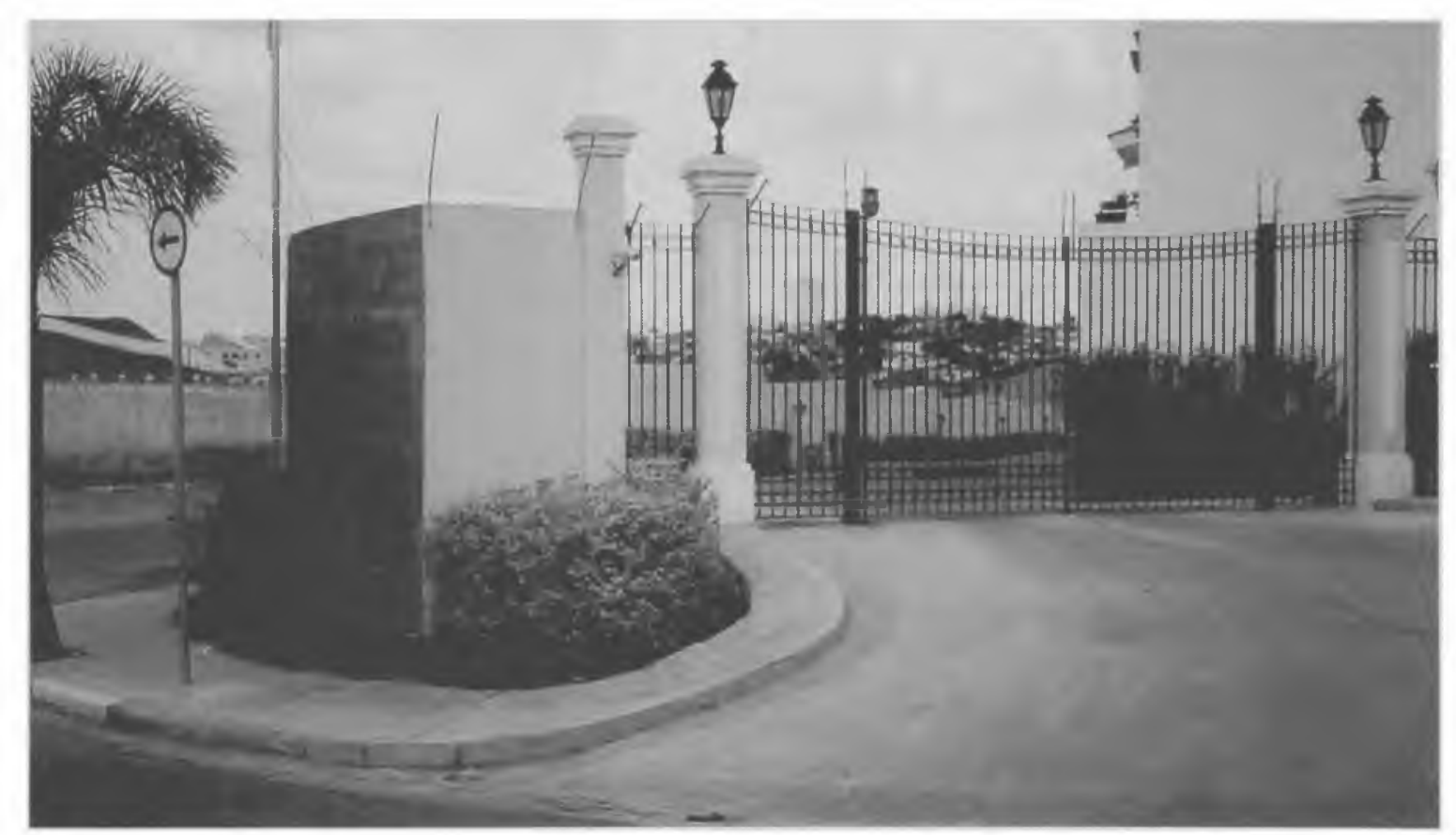

Foto 7: Villas de São Francisco. Ruas asfaltadas

Fonte: Foto da autora 
A idéia da "rua-pátio", da rua um tanto larga, reclusa, atrás dos muros, com canteiros e jardins, própria a usos múltiplos, denotando uma das transformaçōes do que se convencionou chamar de "vila" (conjuntos de residências de mesma arquitetura, mesmo partido, mesmos materiais, mesmo estilo arquitetônico, implantados no interior do quarteirão ou de um terreno maior) poderia ser melhor explorada pelos arquitetos. Estes deveriam buscar maneiras de atrair os moradores para esse espaço, colocando bancos e pergolados, pequenos muros, criando cantos e recantos onde as pessoas pudessem ficar conversando, observando, lendo - como numa praça.

"People live outdoors as well as inside the home; therefore the outdoor environment should be as pleasant and comfortable as possible." An introduction to housing layout. Nova York: Nichols Publishing Company, 1978, p. 22. *

(*) "As pessoas vivenciam o espaço exterior da mesma forma que o interior de suas casas; por isso, o ambiente externo deve ser tão agradável e confortável quanto possível."

A "rua-pátio" deveria ser, a um só tempo, convidativa e local de contemplaçāo. As próprias casas, se tivessem varandas ou pequenos alpendres na frente, funcionando como um prolongamento da sala ou um espaço de transição adequado e diversificado, poderiam contribuir para o uso da "rua-pátio" - que muitas vezes tem permanecido vazia, dada a existência de outros equipamentos e de locais (cobertos ou não) que concentram as pessoas nos momentos destinados ao lazer.

Foto 8: Villa di Firenzi. O asfalto da rua externa tem continuidade no interior da vila Fonte: Foto da autora

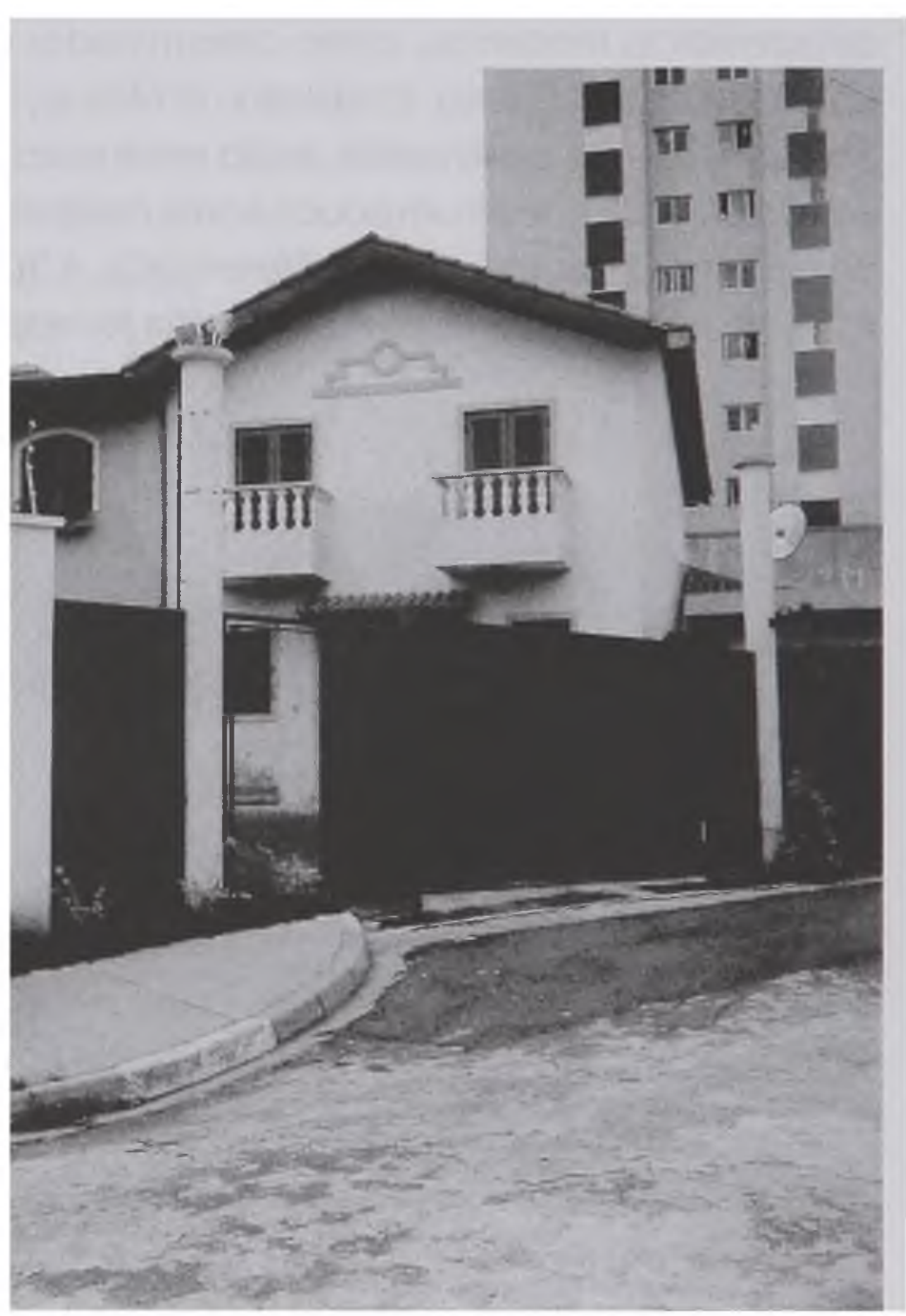




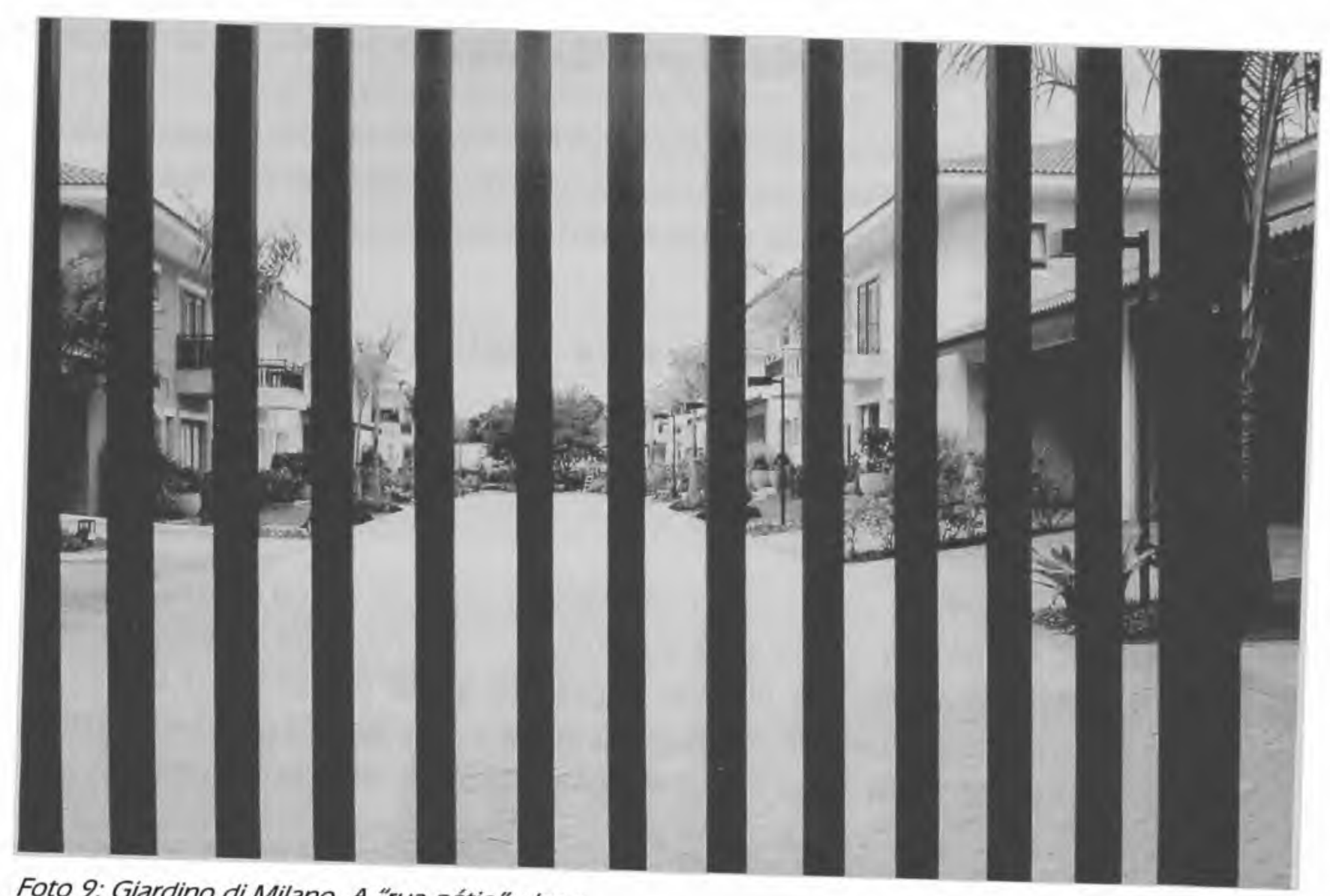

Foto 9: Giardino di Milano. A "rua-pátio" plana Fonte: Foto da autora

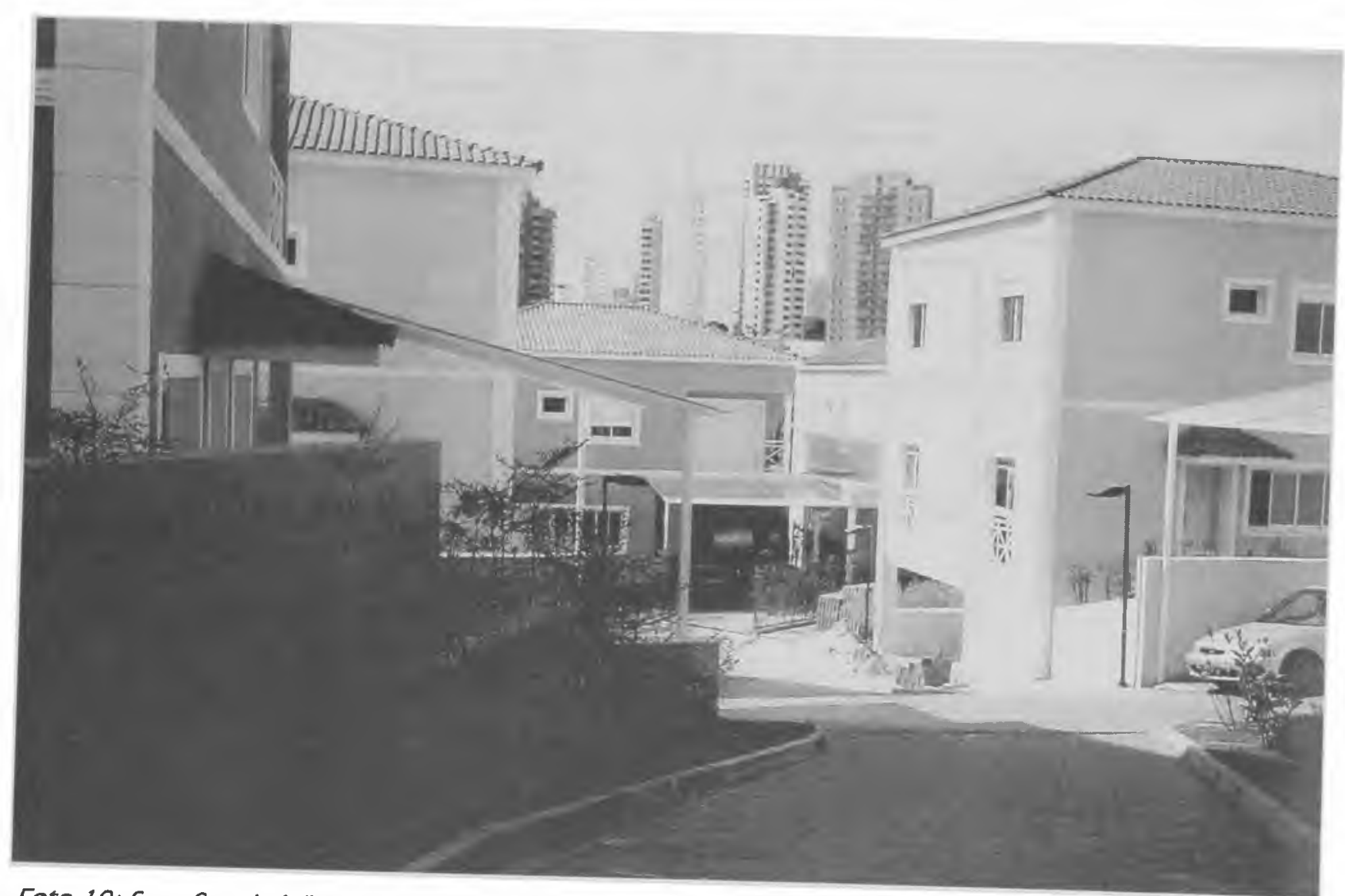

Foto 10: Sans Souci. A "rua-pátio" inclinada

Fonte: Foto da autora 


\section{Caracterização dos Espaços Livres}

Pela análise dos novos conjuntos, percebemos que influenciam na caracterização dos espaços livres de edificação, entre outros fatores, as formas de implantação das residências, a topografia, as dimensões do terreno, o estilo arquitetônico adotado e o projeto paisagístico.

\section{As formas de implantação das residências}

Nas vilas da cidade de São Paulo, adota-se o padrão tradicional de implantação das residências. Estas são construídas sempre paralelas ao alinhamento. As casas ou unidades são dispostas umas ao lado das outras, acompanhando as ruas e pátios ou a "rua-pátio".

Gordon Cullen, em sua obra Townscape, comenta que, enquanto uma obra isolada no campo é "experienciada" como um trabalho de arquitetura, meia dúzia de edificações agrupadas possibilitam uma arte diversa. As pessoas podem caminhar por entre as casas, descobrir espaços, ficar surpresas cada vez que dobram uma esquina - reação essa gerada pela composição do conjunto e que não se faz notar na construção individual, isolada das demais ${ }^{5}$

As novas vilas (como as antigas) são agrupamentos de casas. Se a implantação de suas residências fosse entendida como um trabalho de composição, tornaria possivel a criação de espaços diferenciados, surpreendentes e instigantes aos usuários e visitantes.

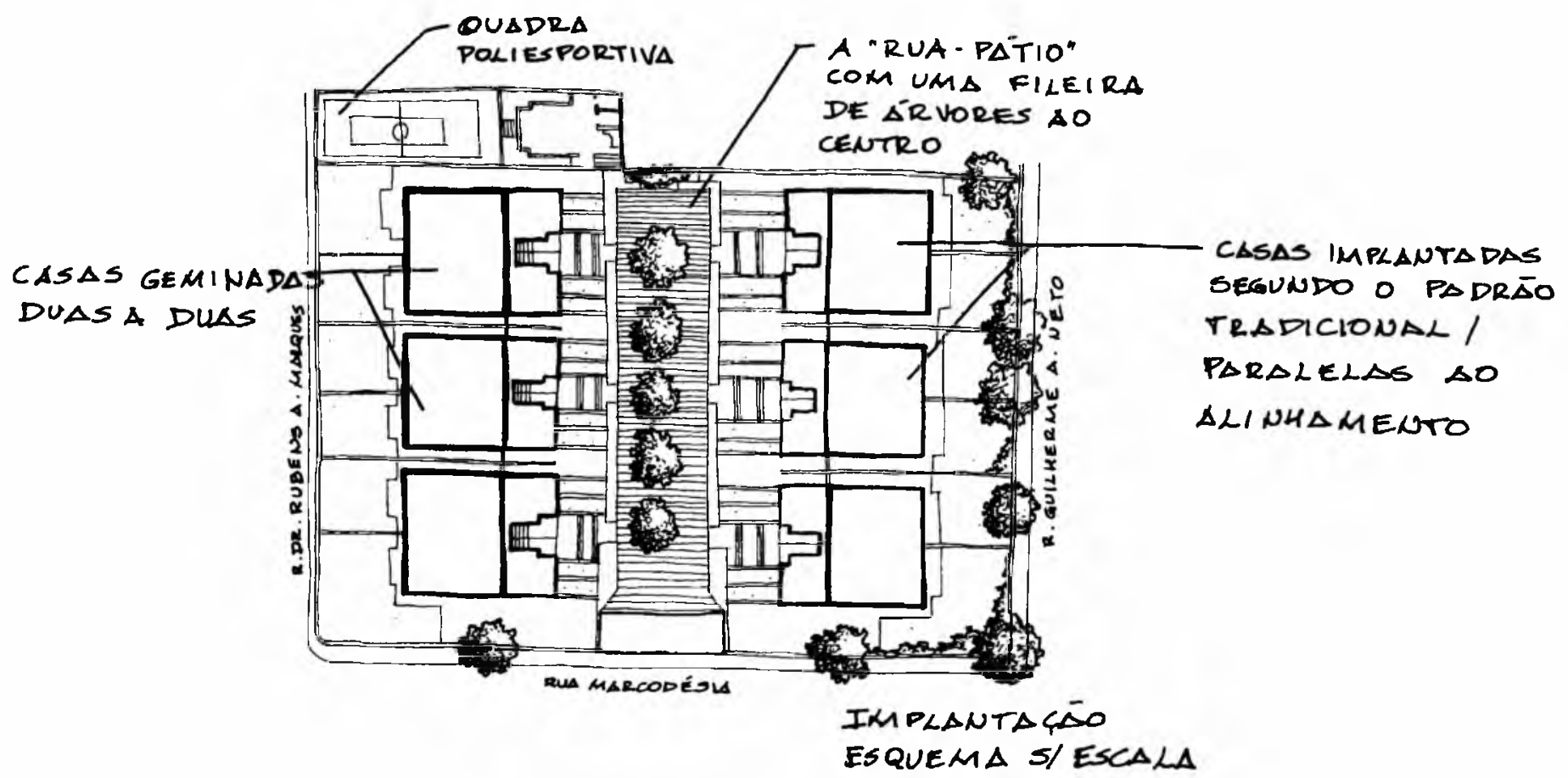

Figura 11: Los Alamos. Casas geminadas duas a duas, paralelas ao alinhamento (Implantação Esquemática). Fonte: Autora

(5) In: An introduction to housing layout. Nova York: Nichols Publishing Company, 1978, p.22.

Paisagem
Ambiente
Ensaios
13

São Paulo n. 13 p. 201229 dez. 2000 
Nos mews contemporâneos de Londres, por exemplo, como podemos ver na obra An introduction to housing layout, há uma preocupação com o percurso, e com as visuais criadas. Construções elevadas, caminhos desencontrados, esquinas, espaços de transição e diferenças de nível são utilizados para reforçar os efeitos que se procura obter com a própria implantação - com casas ao redor de pequenos pátios ${ }^{6}$

Aqui, as construções, isoladas, geminadas ou agrupadas ladeiam a "rua-pátio" em dois ou três de seus lados - não existe a intenção de se criar subespaços; ao contrário, ao que parece, o que se almeja é, na maioria dos casos, a grande área de uso comum, separando as edificações.

No Brooksville, as casas isoladas estão distribuídas nas duas laterais da rua. No Los Álamos Condomínio, faz-se notar a mesma distribuição, agora com as casas geminadas duas a duas. No Espaço Mobile, as residências, agrupadas em dois "edifícios horizontais", conformam um "L". acentuando a idéia do pátio nos espaços livres. No Sans Souci, isto também acontece, mas agora as casas estão implantadas em três dos lados da "rua-pátio".

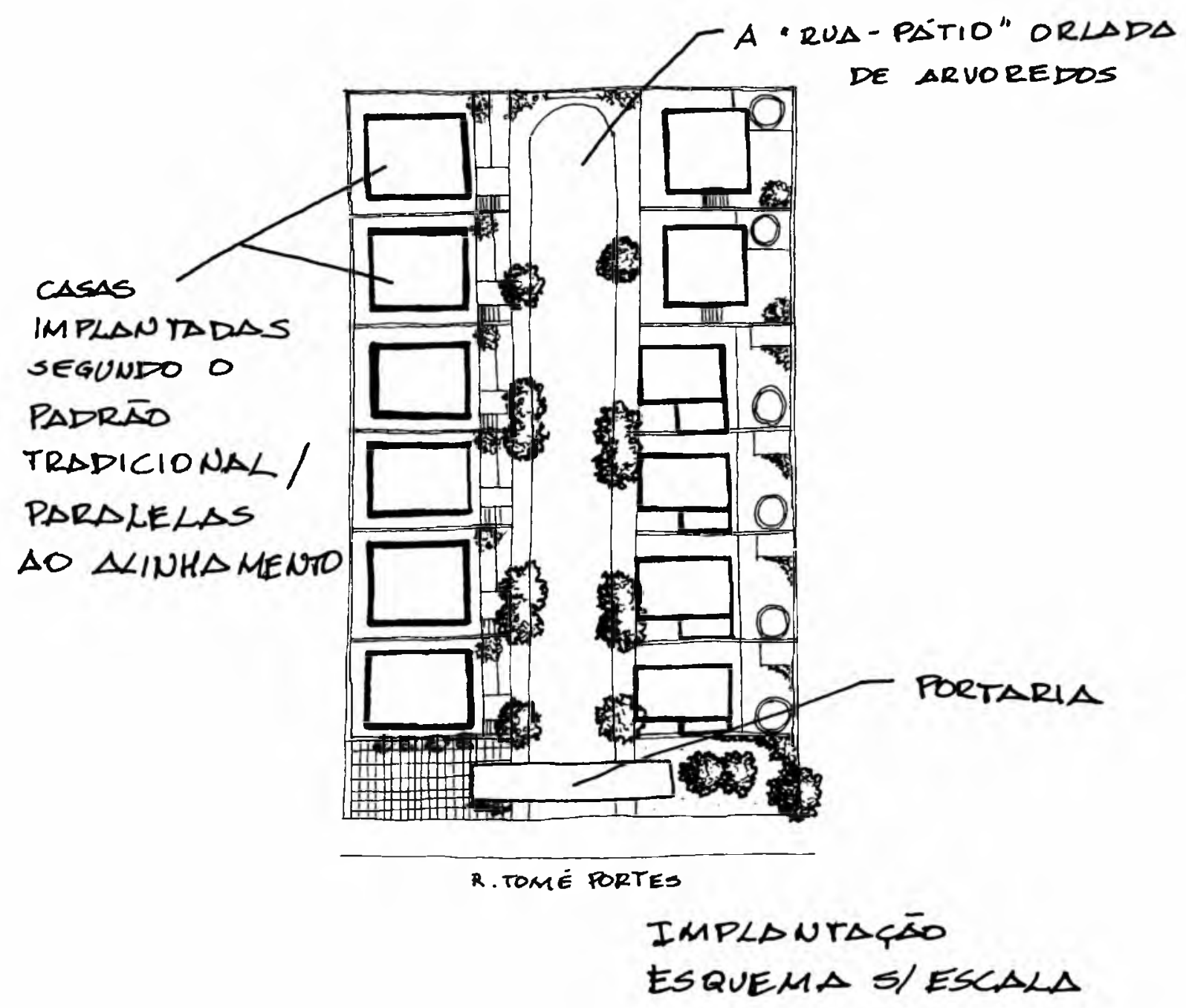

Figura 12: Brooksville. Casas isoladas paralelas ao alinhamento Fonte: Autora

(6) Idem, ibid. 


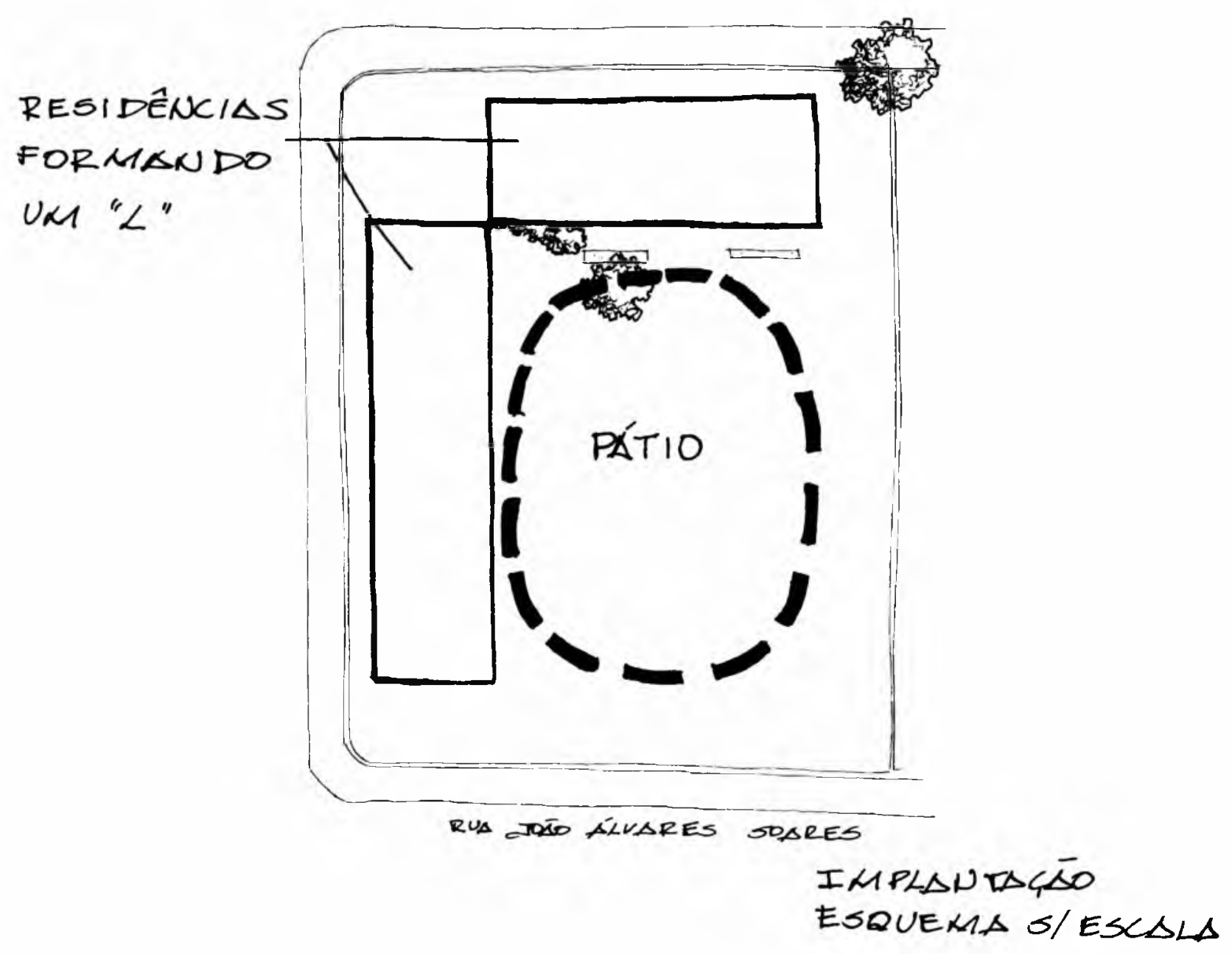

Figura 13: Espaço mobile. A implantação reforça a idéia de pátio. (Implantação Esquemática) Fonte: Autora

Essas formas de implantaçăo têm um vínculo muito forte com o nosso passado, com as tradições da cidade brasileira (casas ao longo das ruas, geminadas, com fachadas contínuas, ou isoladas umas das outras) e, ao mesmo tempo, possuem também um vínculo com as vilas do início ou de meados do século, agora sem a rua estreita e com espaços livres de maiores dimensões.

Evidentemente, existem outras soluções, algumas das quais verdadeiramente simples, como criar uma ou outra variação na disposição das unidades residenciais. No entanto, muitas vezes, a própria configuração ou as dimensões do terreno e nossa tradição (tanto a da cidade como a de nossas vilas) fazem com que se recorra ou se deseje o usual.

\section{A topografia}

Para os moradores dos novos conjuntos, talvez fosse preferivel o terreno plano ao inclinado, principalmente para os que almejam um uso mais intenso dos espaços livres lestes não 


\section{AS CASAS ESTÃO DISPOSTAS \\ EM TRÉS DOS LADOS DA "RUA-PÁTIO"}

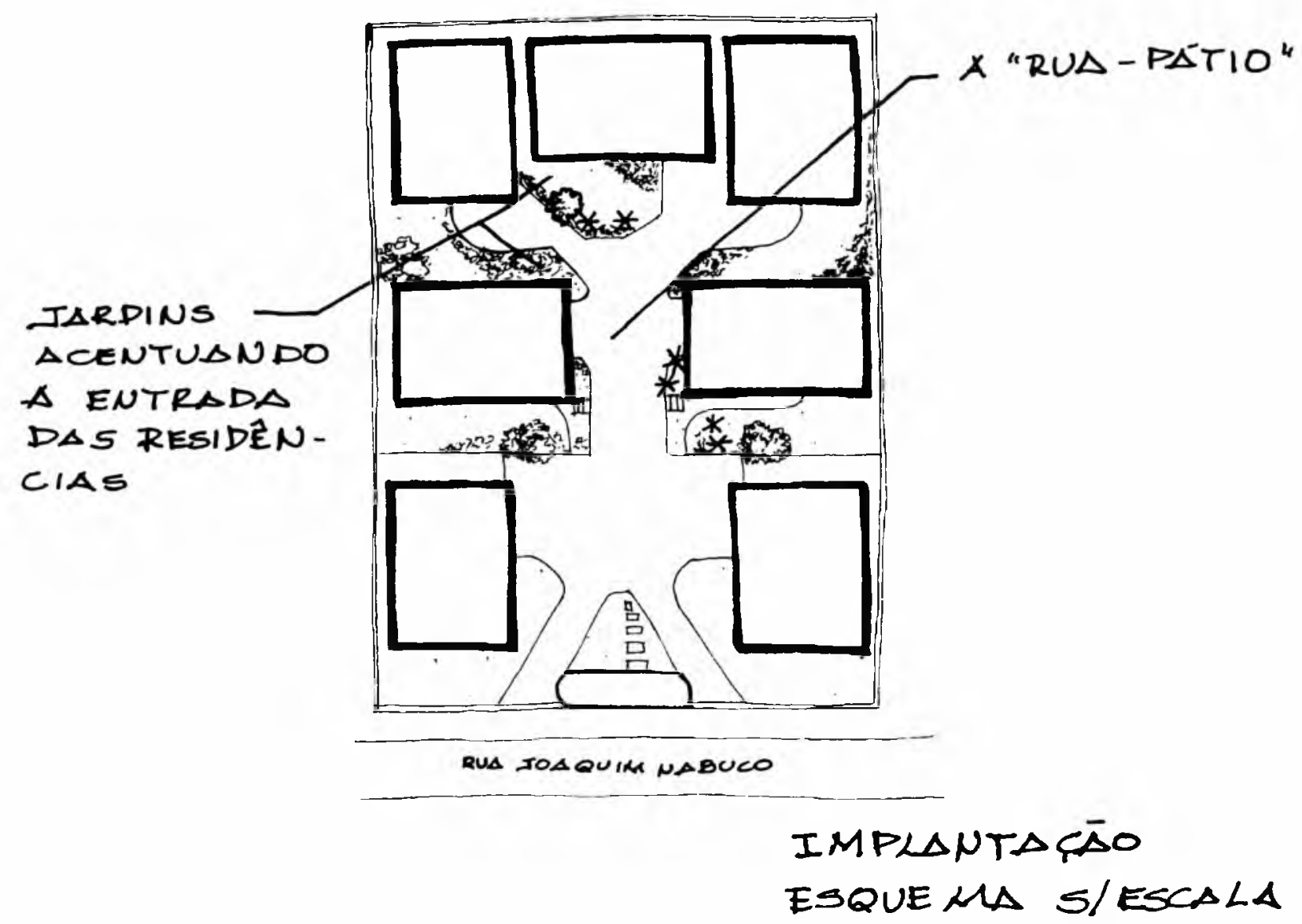

Figura 14: Sans Sauci. As casas "fecham" a "rua-pátio" (Implantação esquemátical Fonte: Autora

podem ser escalonados, com patamares, quando há uma grande variação de nível, porque devem garantir também o acesso dos automóveis às residências). No entanto, grandes lotes inclinados em zonas de uso estritamente residencial - onde não se poderiam erguer edifícios de apartamentos e que, devido ao alto valor do terreno, seria economicamente inviável construir uma única residência - são propícios à implantação de vilas. Um grupo de casas devidamente distribuídas em tais áreas é um investimento lucrativo para os construtores, ao mesmo tempo em que corresponde aos anseios da classe média alta, atraída pela idéia dos condomínios fechados.

Dessa forma, nem sempre o terreno é plano. $E$, sendo inclinado, não são muito variadas as soluções adotadas. Normalmente, as construções acompanham a topografia.

No Brooksville, por exemplo, o terreno está em declive no sentido longitudinal e as residências realçam tal declividade ao serem locadas em níveis diferenciados, no sentido da inclinação. A "rua-pátio" principia no ponto mais alto e termina na extremidade mais baixa do terreno. 


\section{AS CASAS SCOMPANHAM}

\section{O TERPENO}

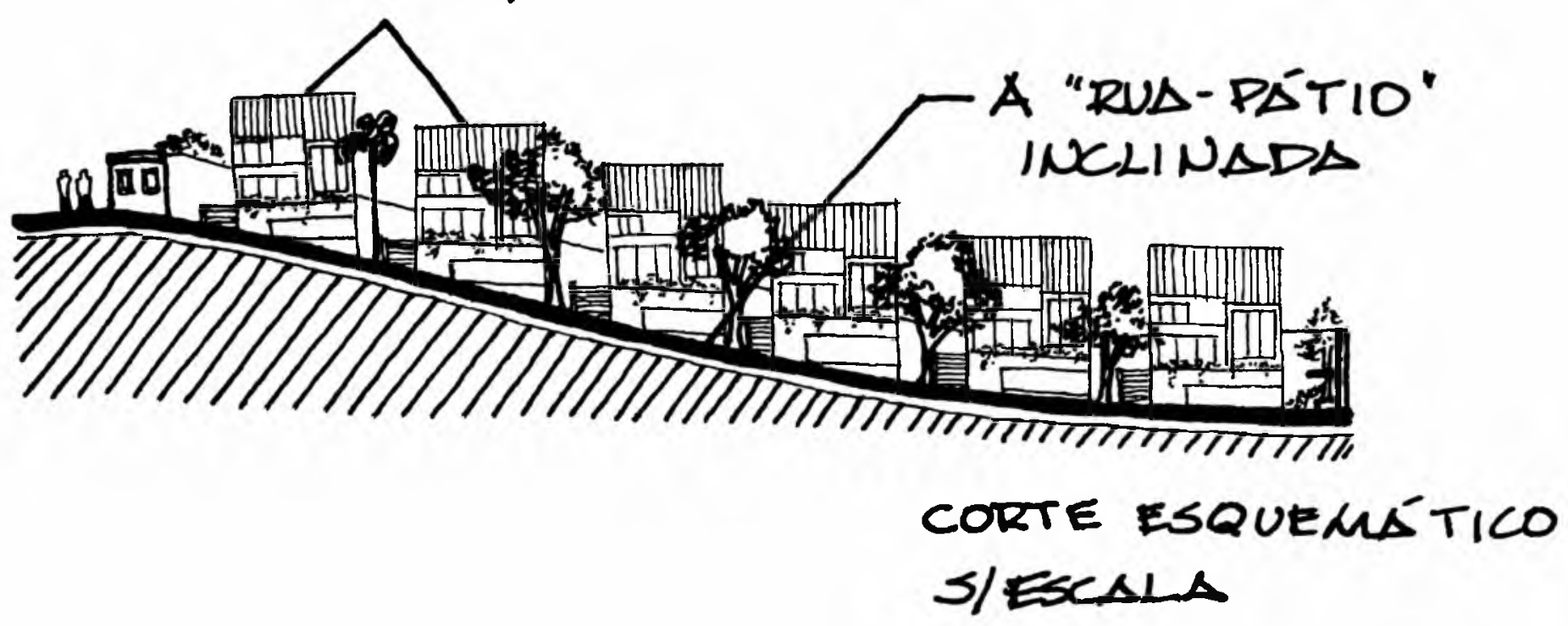

Figura 15: Brooksville. Terreno em declive no sentido longitudinal /Corte Esquemático/ Fonte: Autora

Já a área destinada à construção do Los Álamos Condomínio possuía uma declividade no sentido transversal. O autor do projeto, o arquiteto Fernando Zacharias, decidiu, neste caso, fazer a "rua-pátio" plana e colocar metade das casas em nível mais elevado que o dessa rua de uso comum, e a outra metade, um pouco mais abaixo.

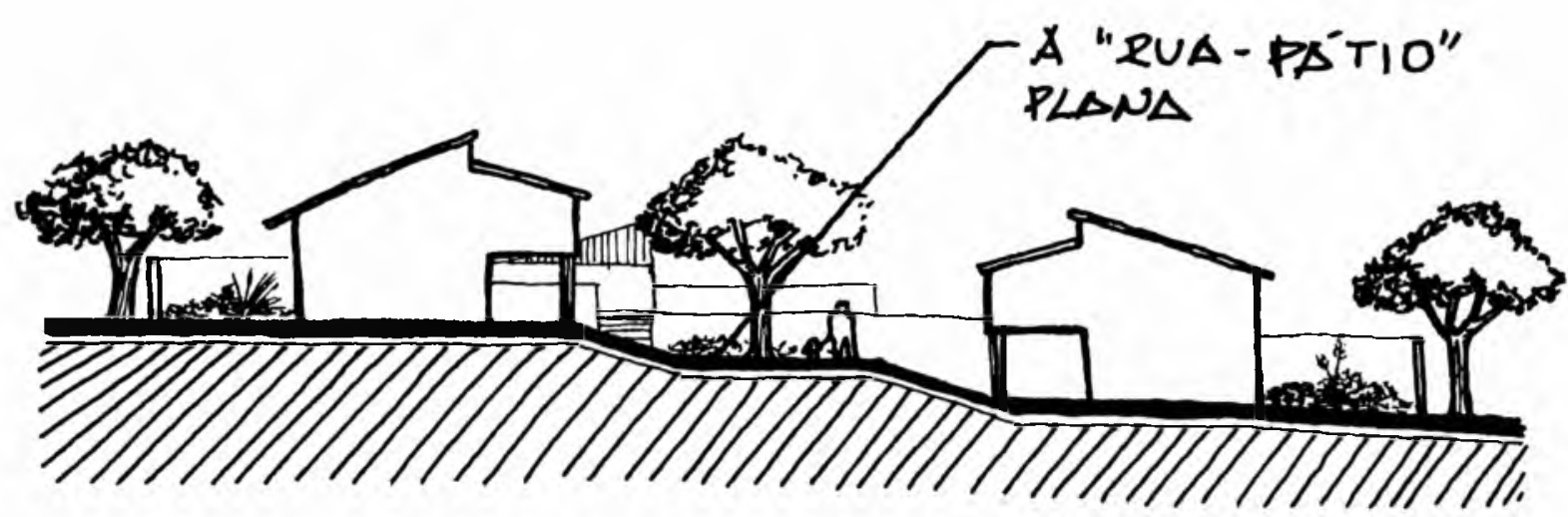

CORTE ESQUEMÁTICO S/ ESCALA

Figura 16: Los Álamos. Casas acima e casas abaixo da "rua-pátio"(Corte Esquemático) Fonte: Autora São Paulo n. 13 p. 201229 dez. 2000 
Em terrenos praticamente planos ou com uma inclinação relativamente pequena, são desnecessários movimentos de terra ou soluções mais complexas. As edificaçōes são implantadas, então, quase no mesmo nível da "rua-pátio", não sendo muito expressivo o desnível. Por vezes, o terreno é aplainado para se obter esse efeito - de ruas e casas no mesmo plano.

Para quem está do lado de fora da vila, quando existem portões que permitem sua visualização, o terreno aplanado permite uma boa visão dos espaços livres de edificação e das construções (o que também se deve ao fato de adotar-se, freqüentemente, a forma tradicional de implantação, com as casas alinhadas, paralelas à rua central). O mesmo não acontece quando o terreno é inclinado no sentido longitudinal (quanto maior a inclinação, menor a possibilidade de se vislumbrar com clareza todo o conjunto, considerando-se também a existência dos muros e portōes que cerceiam o ângulo de visão).

Percebe-se, assim, que a topografia influencia a caracterização dos espaços livres lque podem ser planos ou inclinados) e possibilita uma melhor ou pior visualização desses espaços para quem está do lado de fora da vila. Além disso, a topografia tem seu papel no traçado e nas transformações da paisagem urbana. Quando as casas de um determinado conjunto são erguidas num mesmo nível, tendo todas a mesma altura, configuram um fragmento do tecido urbano que, na paisagem, apresenta os telhados todos nivelados, com algumas árvores entre eles. Quando essas mesmas casas são erguidas em um terreno demasiadamente inclinado, aparecem escalonadas na paisagem: paredes e telhados se intercalam até a edificação mais elevada ou são ocultados por essa edificação, dependendo do lugar onde se encontra o observador.

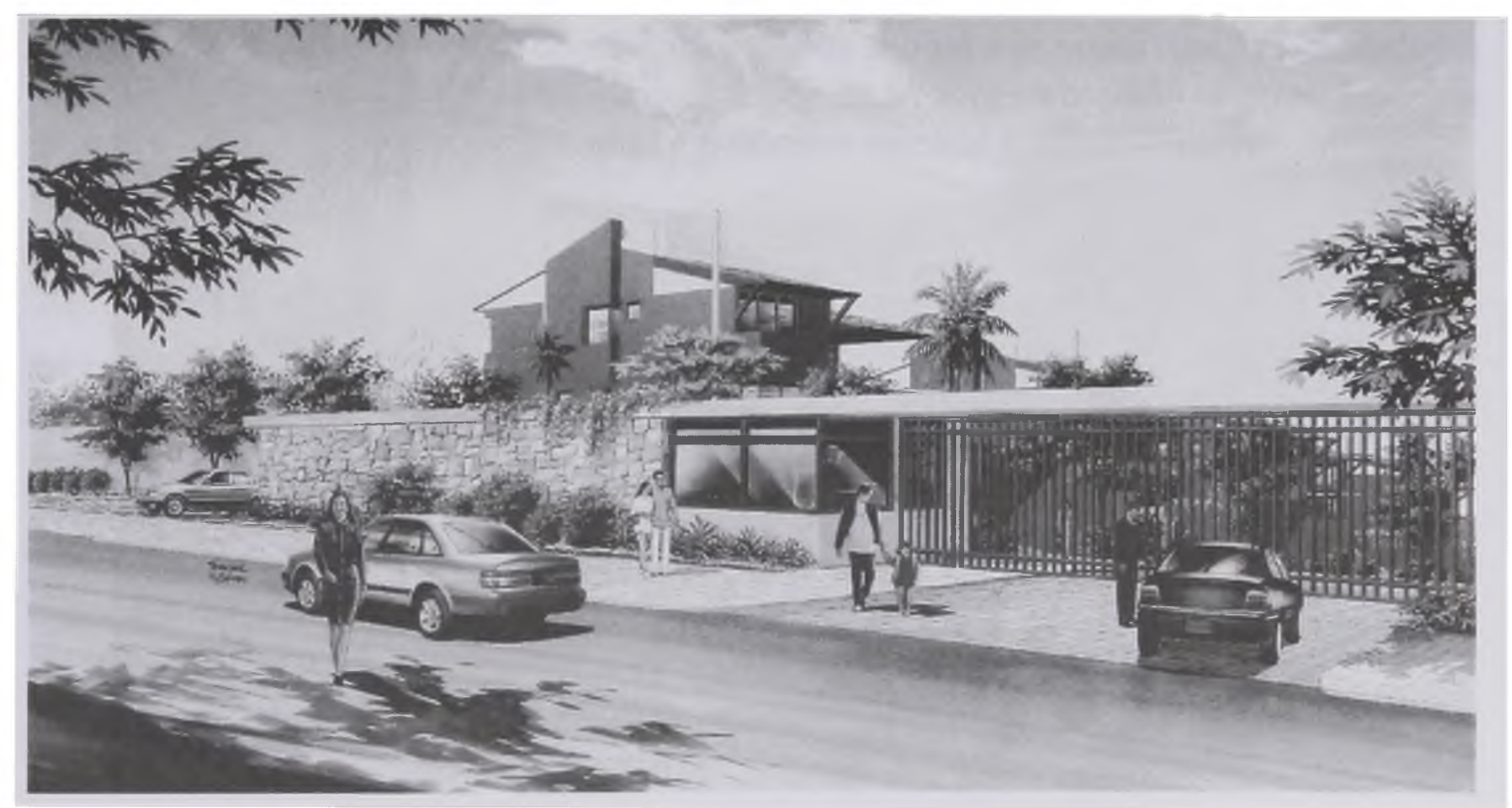

Foto 17: Brooksville

Fonte: (Perspectiva do catálogo) Darpan/Lopes 


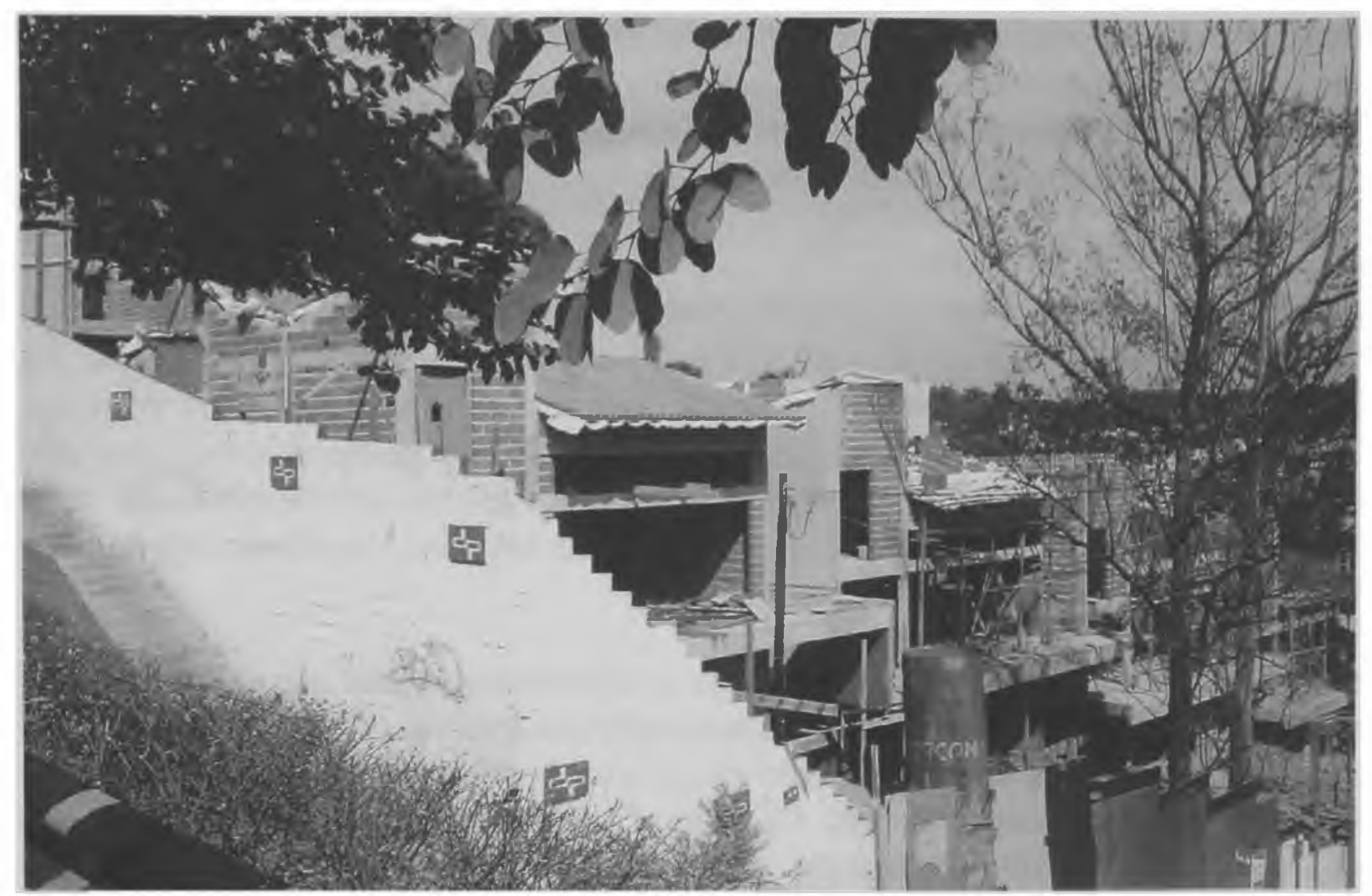

Foto 18: Brooksville na época da construção. As casas acompanham o terreno Fonte: Foto da autora

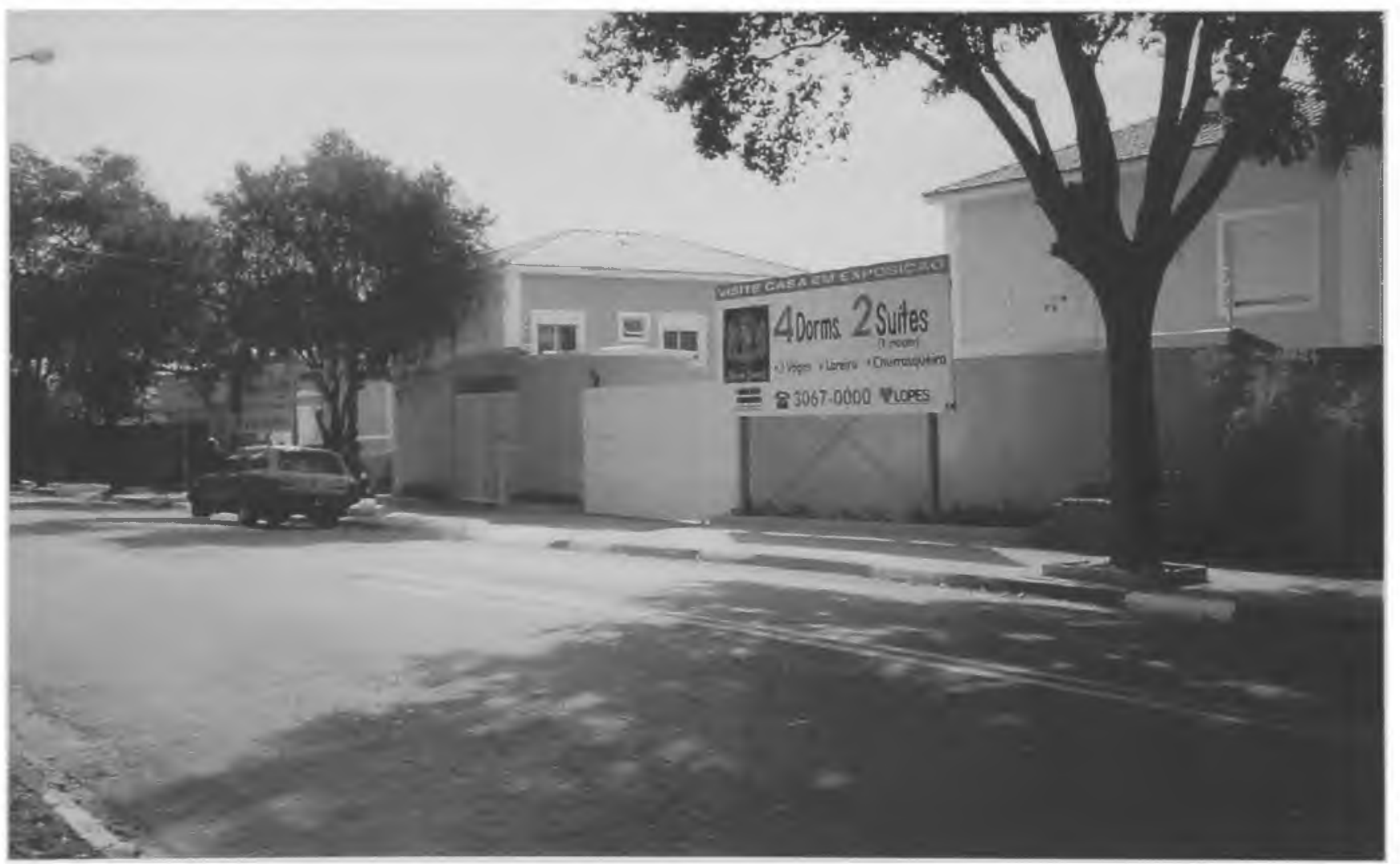

Foto 19: Vista externa de Sans Souci. Só é possivel avistar o telhado das casas próximas à rua principal Fonte: Foto da autora

\begin{tabular}{r|l|lll}
218 & $\begin{array}{l}\text { Paisagem } \\
\text { Ambiente } \\
\text { Ensaios } \\
13\end{array}$ & São Paulo n. 13 p. 201 & 229 & dez. 2000 \\
\cline { 3 - 3 } & & & & \\
& &
\end{tabular}




\section{As dimensões do terreno}

As dimensōes do terreno, aliadas à legislação correspondente à zona de uso residencial em que é implantado o conjunto, irão determinar não apenas o número de unidades residenciais (e suas áreas úteis, variando estas de acordo com o número de casas almejado), mas também a área disponível para os espaços livres de edificação.

Nos terrenos menores (geralmente de forma retangular), situados em bairros mais valorizados, de uso estritamente residencial, só existe uma "rua" interna na vila, com número reduzido de casas, a qual é rodeada ou ladeada pelas edificações. Evidentemente, considerando-se que os conjuntos implantados em tais lotes destinam-se à classe média alta, essa rua é relativamente larga e recebe um tratamento paisagístico, por vezes bastante detalhado. A área dos terrenos varia entre 1.900 e $9.000 \mathrm{~m}^{2}$ (embora a maior parte não possua mais que $3.000 \mathrm{~m}^{2}$ ) e a área útil das residências fica entre 200 e $550 \mathrm{~m}^{2}$, como podemos constatar no catálogo de lançamentos residenciais da EMBRAESP ${ }^{7}$

Já nos bairros distantes, os terrenos, quando são maiores (alguns chegam a ter os $15.000 \mathrm{~m}^{2}$ - área máxima permitida pela legislação), ocupam grande parte das quadras, em certos casos, quadras inteiras, possuindo formas variadas. Como é relativamente grande o número de unidades, sua distribuição no terreno requer uma rua mais extensa ou mais de uma rua. Neste caso, esses espaços praticamente deixam de ter características de pátio, como já vimos.

Se, nas antigas vilas, quando o lote a ser ocupado era menor, criava-se um único pátio e, quando maior, dois ou três; nos novos conjuntos, ora se tem a "rua-pátio", ora simplesmente ruas que garantem o acesso às residências. Isso tanto mostra as diferenças na forma de distribuição dos espaços livres e construções entre as antigas e as novas vilas, como confirma o fato de que as soluções adotadas e a quantidade de áreas destinadas a uso comum variam de acordo com as dimensões do terreno e o número de casas implantadas.

\section{O estilo arquitetônico adotado}

As casas que ladeiam ou estão ao redor da área central compõem, ao lado de outros elementos, o cenário das vilas. São o pano de fundo tridimensional. Se conformam fachadas contínuas, estando agrupadas ou geminadas, produzem um efeito; se são geminadas duas a duas, produzem outro; e se estão isoladas, outro ainda. De qualquer forma, a fachada principal das residências, limitando os espaços livres, contribui para sua caracterização. Além disso, acaba por influenciar o traçado e o desenho dessas áreas, harmonizando-se com elas ou criando o contraste.

(7) A EMBRAESP é a Empresa Brasileira de Estudos do Patrimônio e o catálogo citado contém as fichas dos conjuntos horizontais lançados entre 1996 e 1999. 
Nas novas vilas paulistanas cujo estilo pode ser considerado eclético, pós-moderno ou classicizante, têm-se na fachada das residências, elementos, detalhes ou ornamentos que nos remetem a outras arquiteturas ou à arquitetura de outros tempos. Isso, por si só, confere aos espaços livres de edificação uma tonalidade estrangeira ou passadista, rememorando fragmentos de cidades européias e norte-americanas ou mesmo algumas das vilas que lá existem.

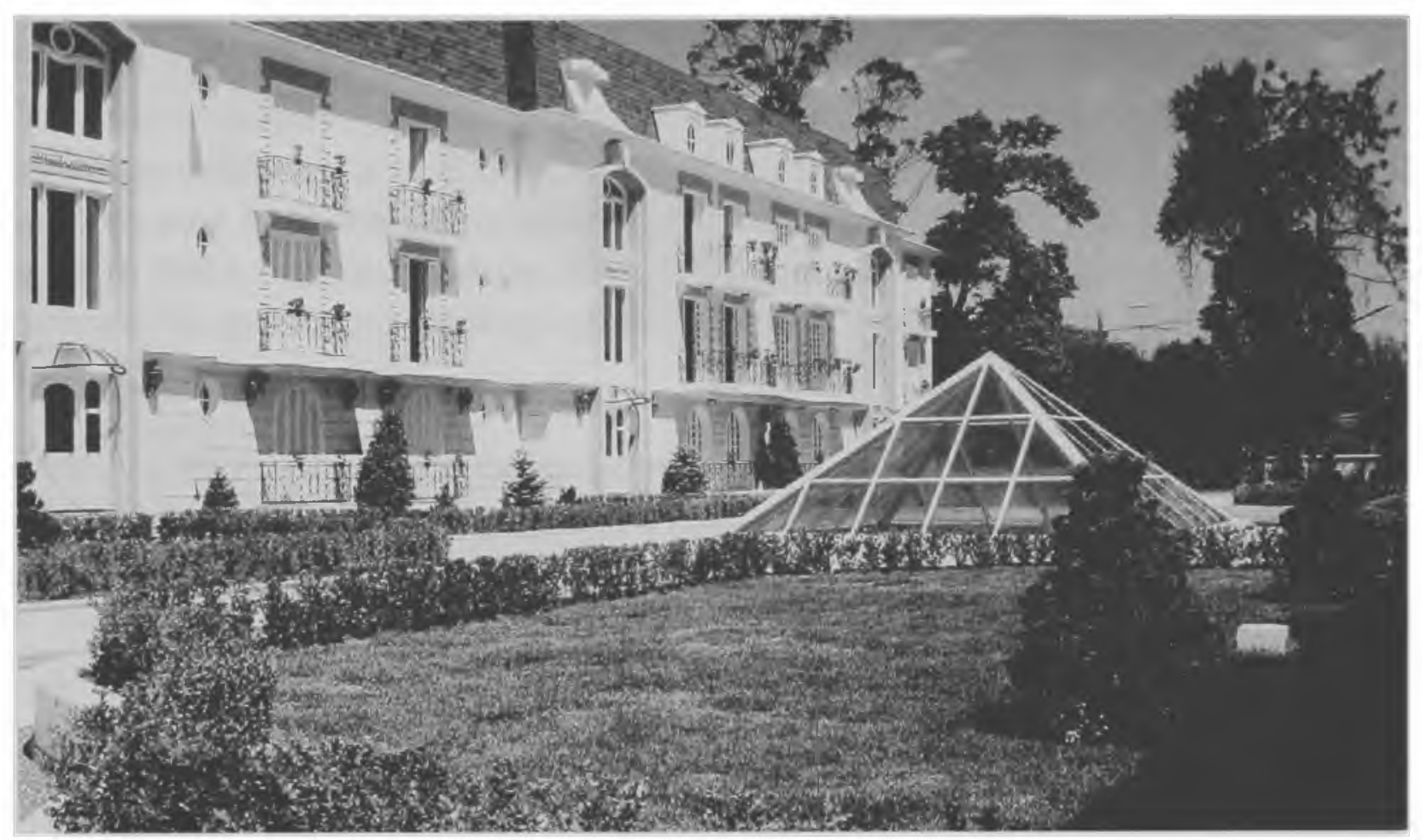

Foto 20: Ville de France. O cenário francês

Fonte: Foto da autora

Nas vilas com traçado moderno ou que apresentam uma "certa modernidade" brasileira, onde se faz uso de elementos como telhas capa-canal, predominam as linhas retas nas edificações. Não há ornamentos. A arquitetura configura, então, um cenário que antes expressa sua brasilidade do que faz menção a construções estrangeiras. Os espaços livres dessas vilas têm também o traçado simples, sem rebuscamentos, com o predomínio evidente do piso sobre a vegetação.

É preciso deixar claro que as vilas são, antes de tudo, conjuntos de residências, grupos de moradias isolados da cidade de alguma forma (seja por estarem implantados no interior dos quarteirões, seja por estarem cercados por muros e grades). Os espaços livres de uso comum, situados entre as unidades residenciais, têm uma importância relevante enquanto locais de lazer e de sociabilidade, locais de uma vivência externa, ainda que não pública, e complementos da moradia. Mas eles são sempre limitados (ou delimitados) pelas contruções e, por isso, a arquitetura exerce grande influência em sua caracterização. Aqueles que moram ou visitam as vilas vêem as residências ao redor dos pátios ou da "rua-pátio"; vêem as portas e janelas, a cobertura, os detalhes, a composição da fachada. E é o estilo adotado nessas construções que determina a "feição" ou o tom do cenário que se delineia. 


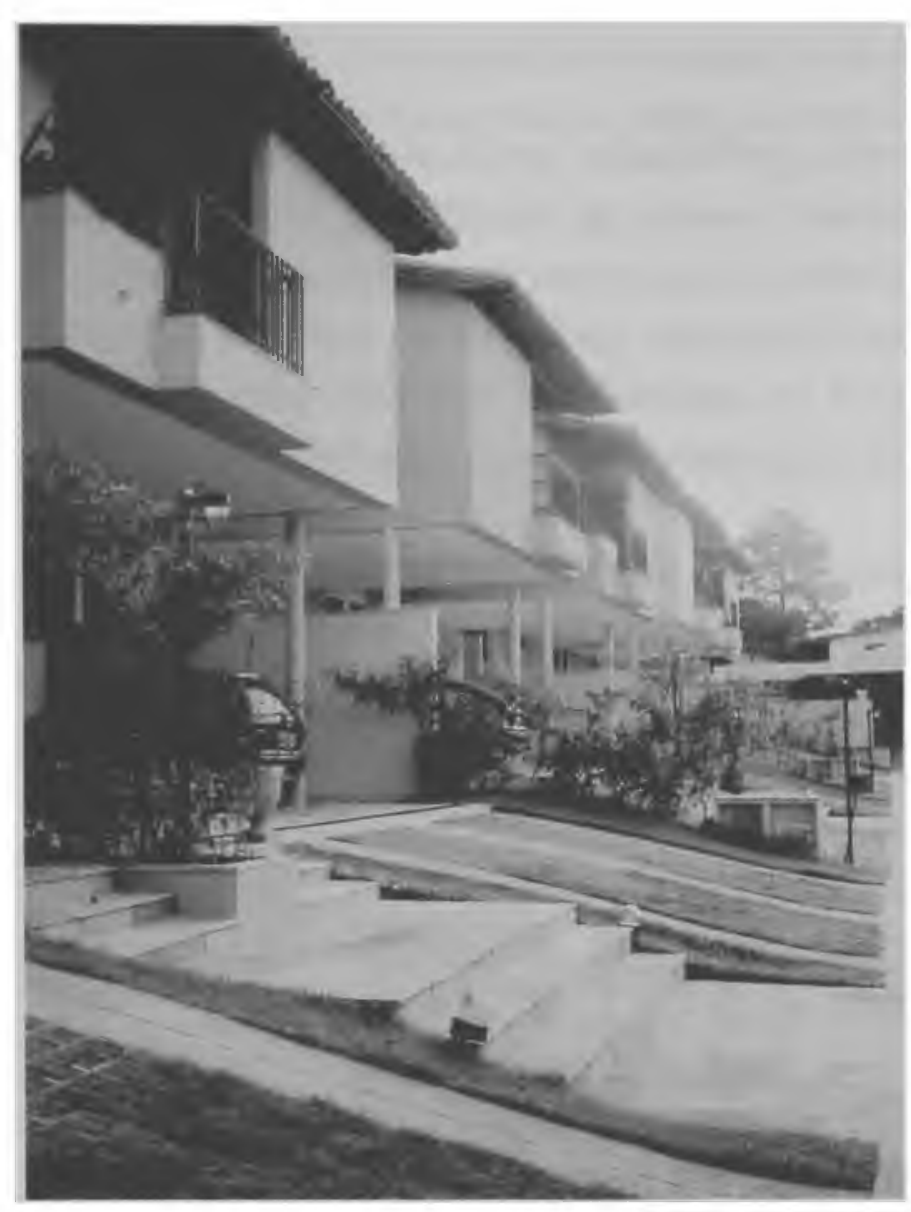

Foto 21: Los Álamos. O cenário brasileiro Fonte: Foto da autora

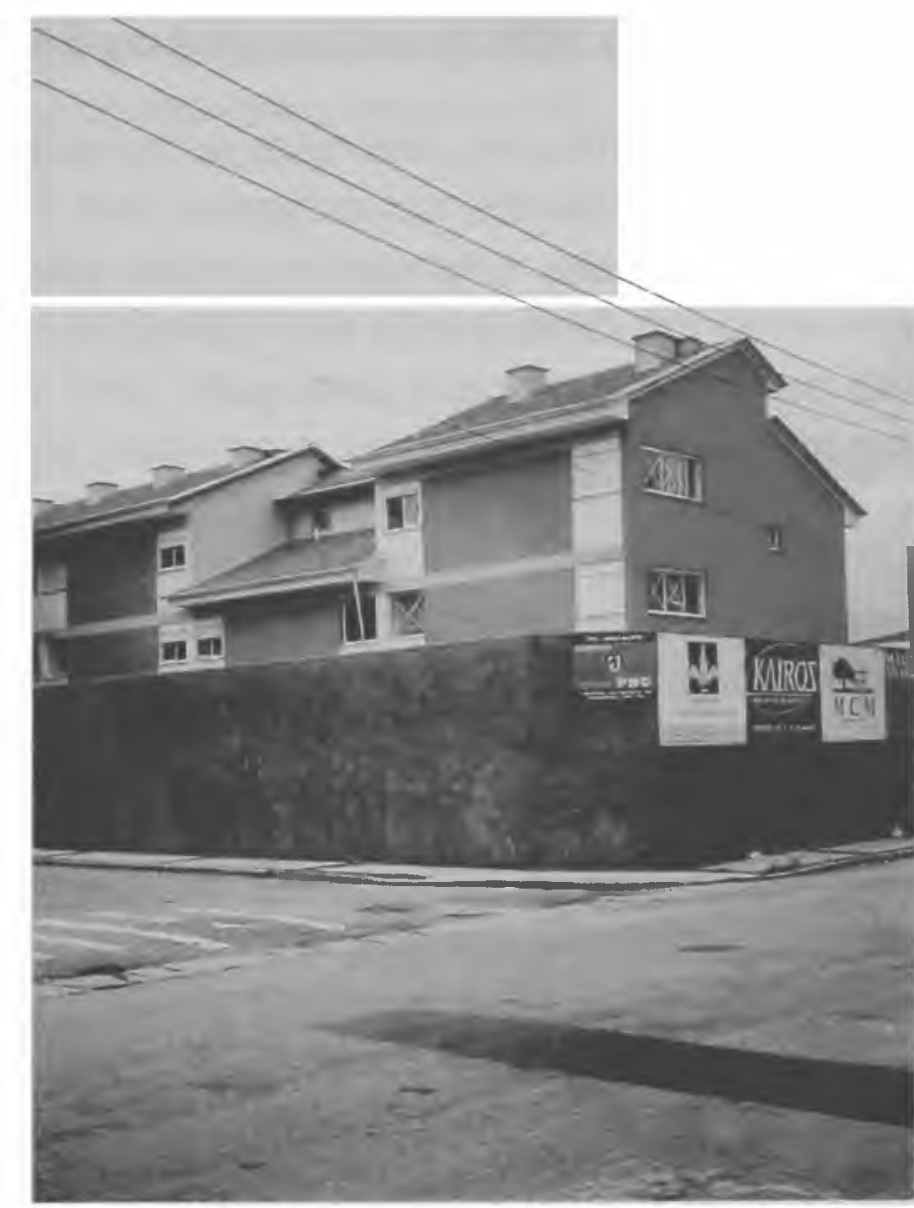

Foto 22: Espaço Mobile. Vista externa do conjunto Fonte: Foto da autora

\section{O projeto paisagistico}

Diferentemente da grande maioria das antigas vilas, cujos espaços livres de edificação, bastante simples, apresentavam um ou outro canteiro de vegetação, criados, eventualmente, pelos próprios moradores (conjuntos como o Parque Residencial Savoia, por exemplo, com piso diferenciado, canteiros projetados, fontes e pergolados eram, na verdade, raras exceções), boa parte das novas vilas paulistanas é dotada de projeto paisagístico.

Este consiste, nesses conjuntos: na escolha da pavimentação dos espaços livres; na distribuição de canteiros e árvores, na ordenação de pequenos jardins; na escolha deste ou daquele exemplar arbóreo, deste ou daquele tipo de vegetação; e na locação de certos elementos como fontes e luminárias. Consiste, ainda, na adoção de determinado estilo (moderno, pós-moderno, clássico, eclético ou passadistal, usualmente de acordo com a arquitetura, ou seja, com o estilo empregado nos espaços construídos.

Interessante é observar que os espaços livres dos conjuntos destinados à classe média alta recebem um tratamento diferenciado daqueles dos conjuntos produzidos para a camada média da classe média, mesmo que sejam idealizados pelo mesmo paisagista. 


\section{A escolha da pavimentaçâo}

Nos conjuntos maiores, com casas de fachada estreita, geminadas, produzidas em série, as ruas internas são asfaltadas; nos conjuntos com um número menor de residências, projetados para a classe média alta, emprega-se um piso diferenciado (na rua com características de pátio); e, nos conjuntos destinados a essa camada social, que possuem garagem no subsolo, adota-se, vez ou outra, o mosaico português, uma vez que os automóveis não têm acesso a esses espaços, sendo desnecessários, portanto, pisos que apresentem uma resistência maior.

Os paralelepípedos, tão comuns nas antigas vilas, já não são mais empregados. Eles tanto eram resistentes, como permitiam a infiltração das águas da chuva e, se fossem adotados hoje, talvez dessem, por si só, nuanças de outros tempos aos novos conjuntos (quando houvesse essa intenção), trazendo à memória de seus usuários e moradores o aspecto das ruas de antigamente.

\section{A distribuição de árvores e canteiros e a ordenação de pequenos jardins}

As árvores aparecem quase sempre ladeando as ruas ou a "rua-pátio", na frente das residências, ou distribuídas linearmente em seu eixo principal. Havendo pequenos jardins ou gramados, alguns exemplares arbóreos são dispostos também nessas áreas. Em um ou outro projeto, há árvores ao fundo, nas proximidades do muro divisor; e não é incomum a idéia de árvores ou arvoretas no quintal das casas.

Os canteiros, quando existem, são locados no espaço entre edificações, sendo mais comuns, entretanto, os pequenos jardins ou gramados em frente das unidades residenciais.

A existência desses jardins ou áreas cobertas com grama em faixas que acompanham a fachada das residências contribui para ampliar a área dos espaços livres de uso comum, embora cada uma das casas "possua" um pequeno trecho. $E$ isso, tanto nos conjuntos de classe média como nos de classe média alta. No Giardino di Milano, a rua interna (para nós a "rua-pátio") possui $8 \mathrm{~m}$ de largura. Mas as residências possuem $4 \mathrm{~m}$ de recuo em relação a essa rua. Tem-se, portanto, uma área com 16 m de largura separando as edificações. Na Villa Reggio e nas Villas de São Francisco, existe uma pequena área gramada em frente das casas, utilizada para estacionamento de veículos, que acaba por aumentar, da mesma forma, a área dos espaços livres de edificação.

\section{A escolha dos exemplares arbóreos e do tipo de vegetação}

"O projeto de paisagismo do Palmeiras Imperiais Private Houses apresenta uma melhor qualidade de vida, onde o verde foi preservado, a vegetação selecionada, para que as texturas e os aromas ofereçam a cada dia uma nova estação, o saber viver a vida sempre sonhada e que agora se 
torna realidade. Um projeto encontrado nos condomínios residenciais de grandes metrópoles." Benedito Abbud (Paisagista). Catálogo Imobiliário do Palmeiras Imperiais Private Houses.

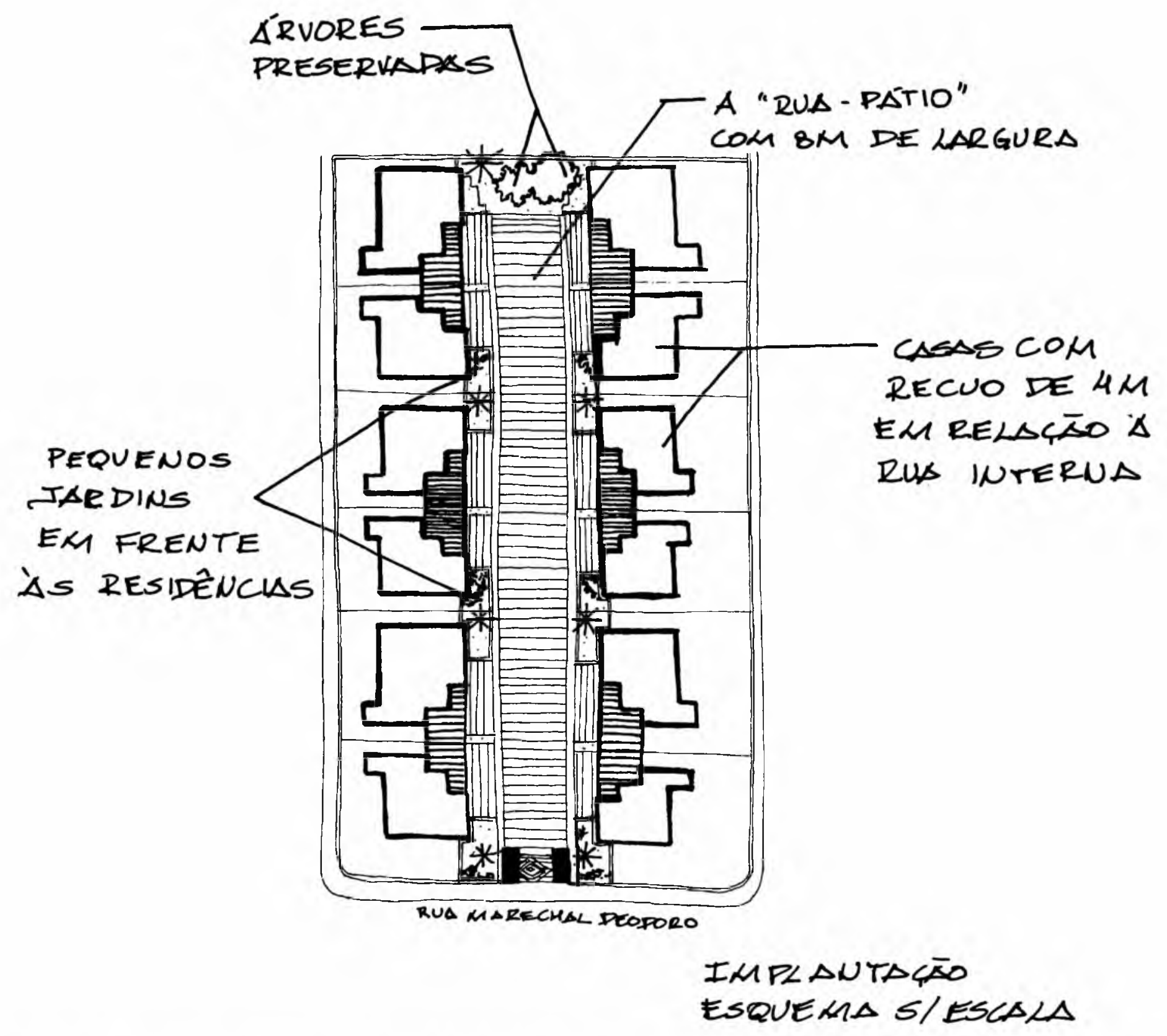

Figura 23: Giardino di Milano. Casas com 4.00 m de recuo em relação à rua interna (Implantação esquemática) Fonte: Autora 
VILLD REGGIO

VISTA PARCISL DO

CONTUNTO

(SEM ESCALA)

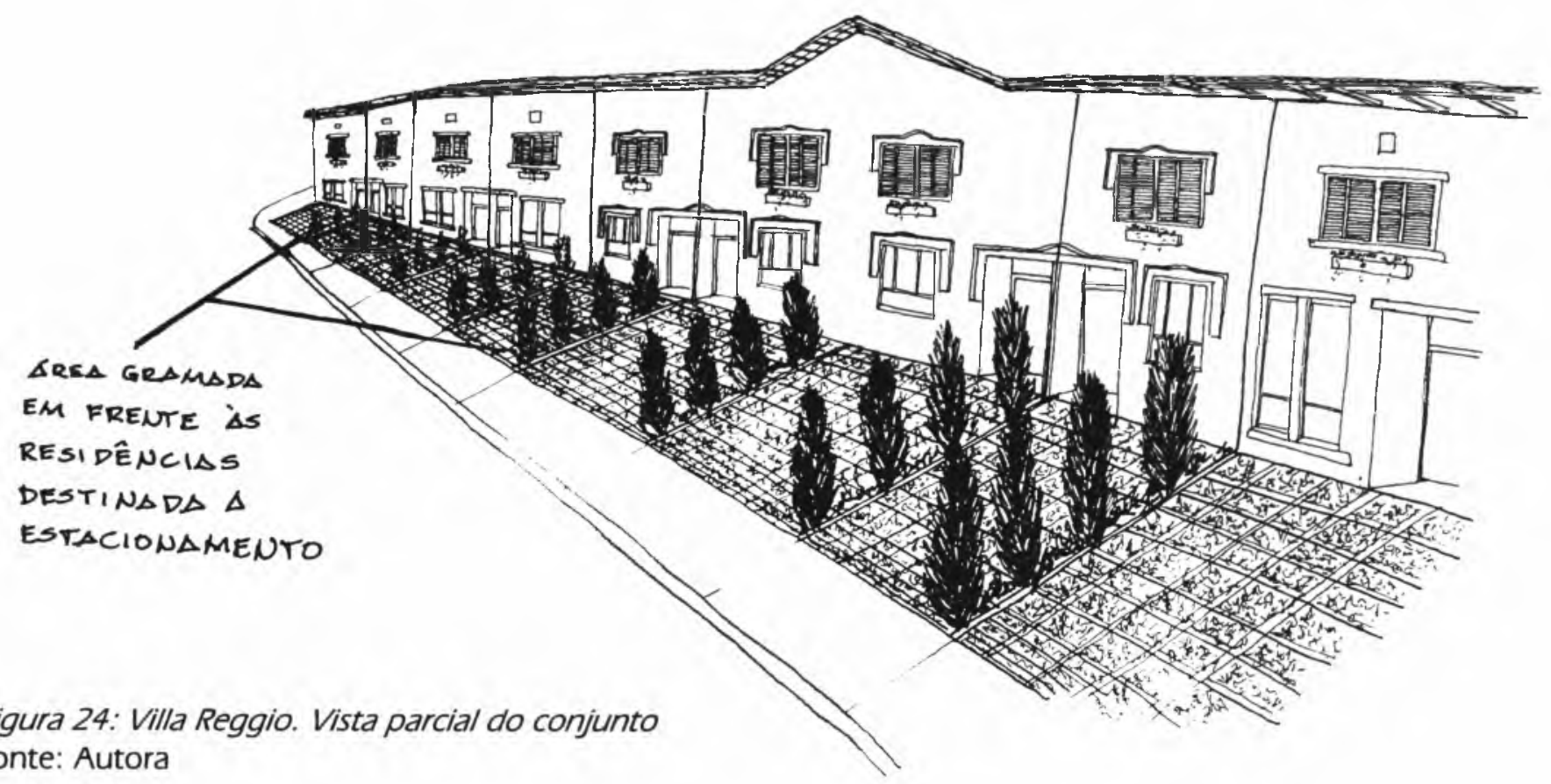

Fonte: Autora

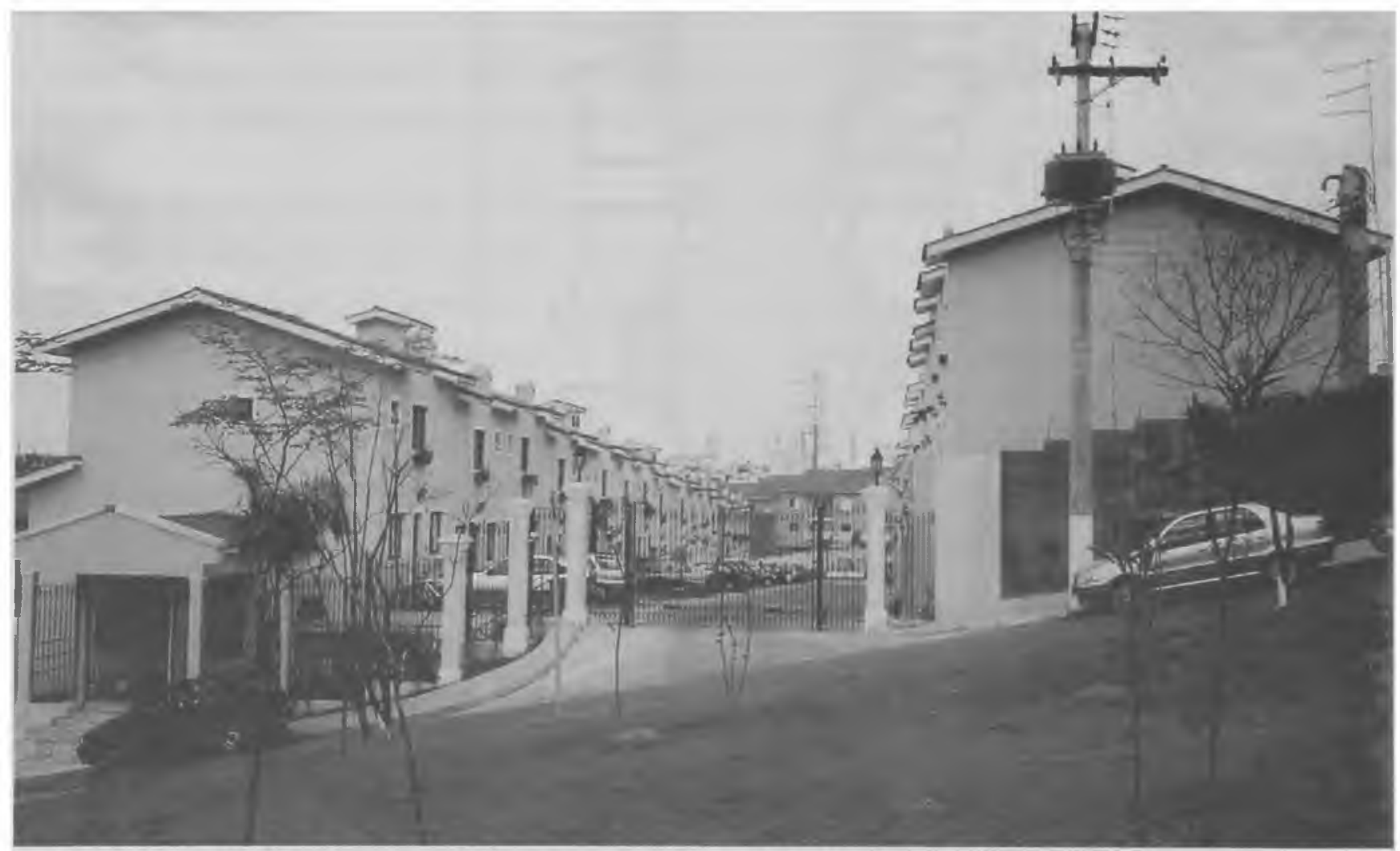

Foto 25: Villas de São Francisco. A área em frente às residências é utilizada para estacionamento de veículos

Fonte: Foto da autora 
Há vezes em que certas árvores, já existentes, são preservadas, integrando-se ao projeto paisagístico. O que não acontece sempre. Normalmente, toda vegetação é retirada do terreno antes de se dar início à construção da vila. Posteriormente, são plantadas árvores e outras espécimes vegetais em locais rredeterminados.

Ao que parece, as árvores escolhidas são de pequeno e médio porte, sendo comuns também as palmáceas. Em determinados projetos, está presente a intenção de se proporcionar coloração e aromas diferenciados a cada estação do ano.

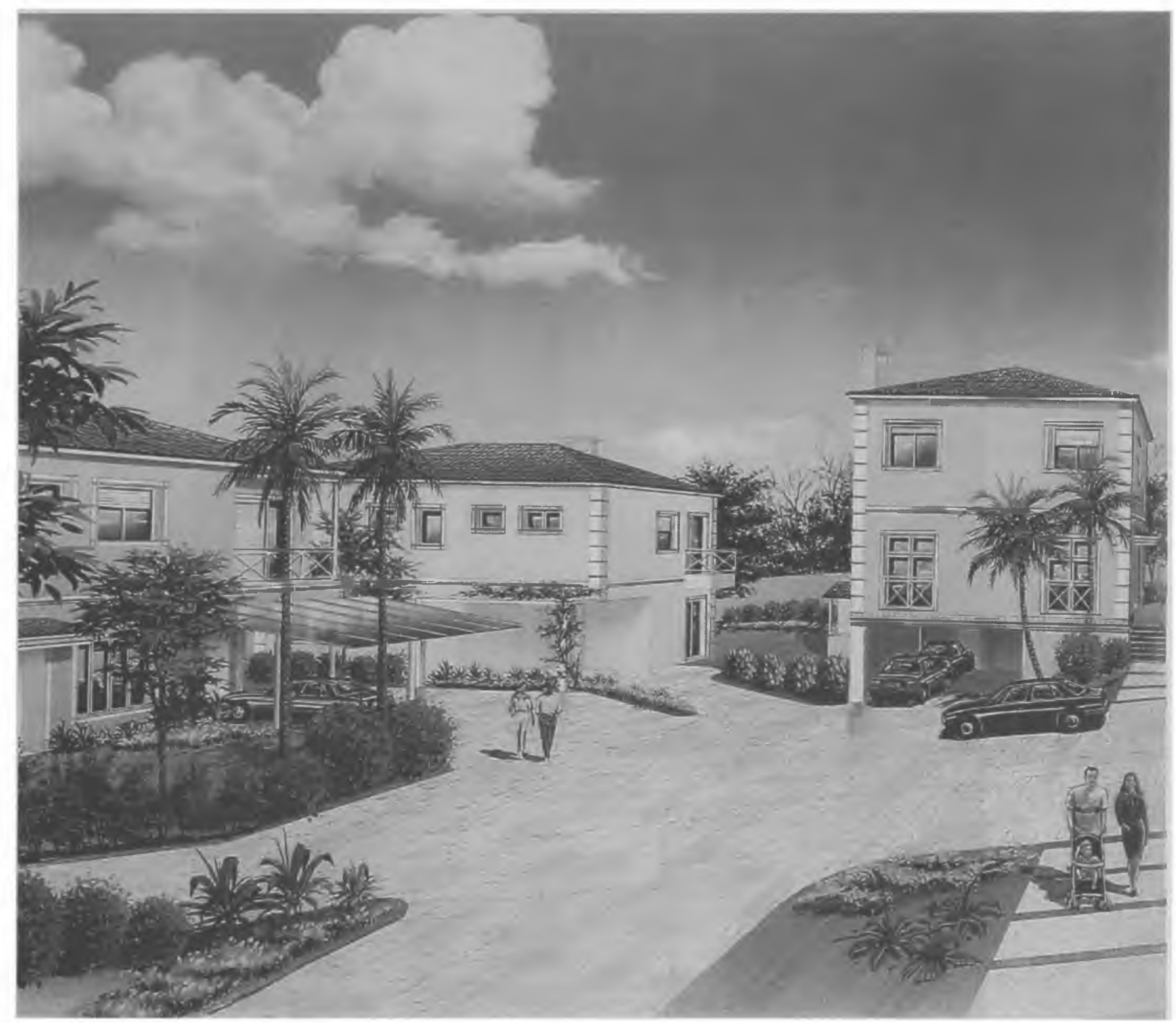

Foto 26: Sans Souci

Fonte: (Perspectiva do Catálogo Imobiliário) Construtora Sampaio Bacos/Lopes 


\section{A locação de elementos como fontes e Iuminárias}

Enquanto as luminárias acompanham as ruas ou a "rua-pátio" por praticamente toda sua extensão, as fontes aparecem perto do muro divisor, na extremidade final da rua interna ou no alargamento de uma das ruas dos conjuntos com um número maior de residências. Mais raramente, situam-se nos jardins ou em locais menos visíveis. No primeiro projeto do Le Premier, a fonte aparecia do lado de fora da vila, enaltecendo a entrada.

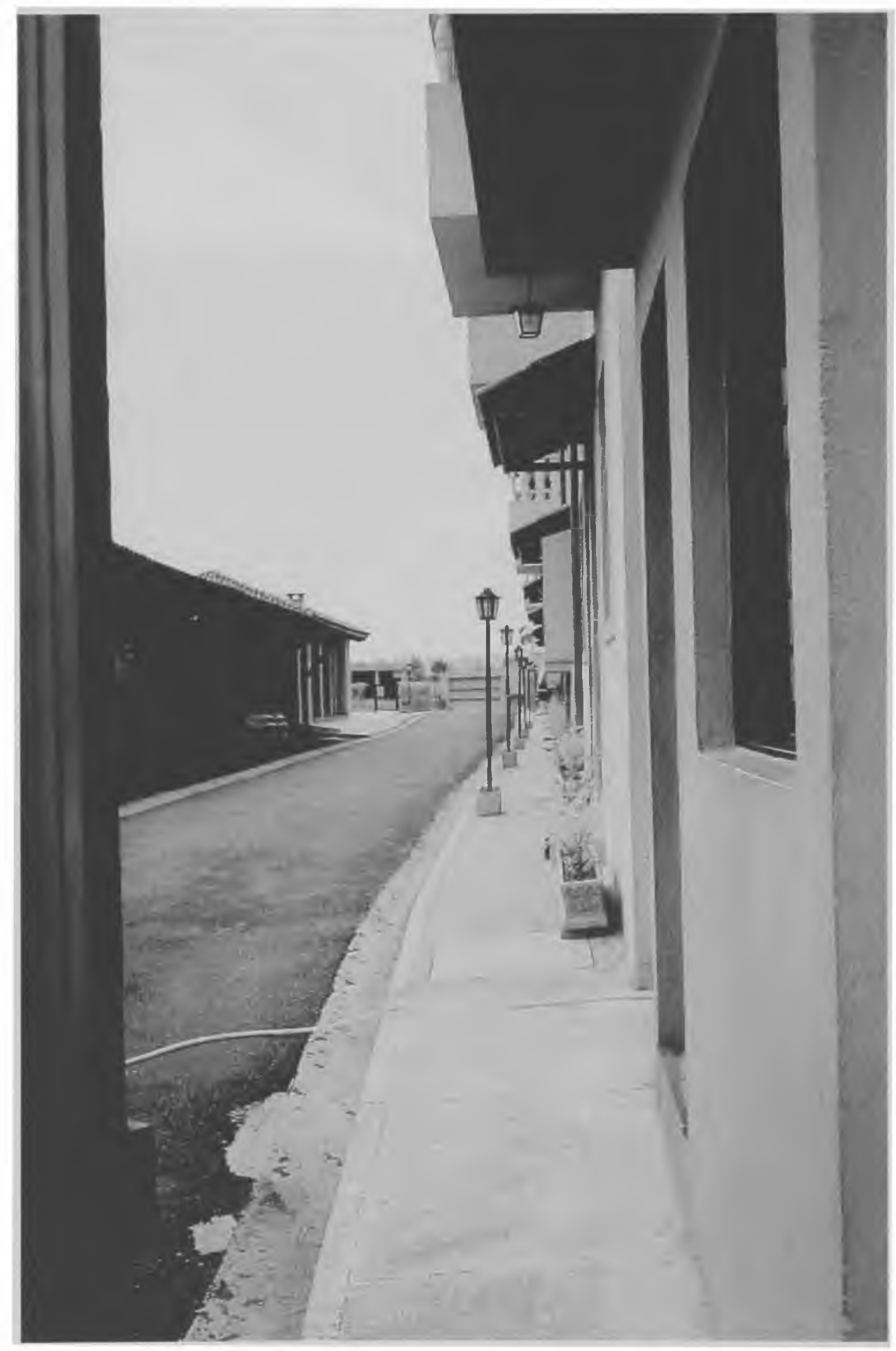

Foto 27: Villa di Firenze. Luminárias alinhadas na calçada

Fonte: Foto da autora 
Na verdade, esse elemento era bastante empregado nos pátios e jardins das "villas" italianas residências de certo luxo e requinte projetadas por arquitetos como Andrea Palladio no renascimento. Nas vilas paulistanas, mesmo nos conjuntos destinados para a classe média (as primeiras vilas foram erguidas para o operariadol, dificilmente havia fontes. Estas apareciam em um ou em outro projeto, estavam longe de ser regra geral. A recorrência a esse elemento tem sido bem mais expressiva nos novos conjuntos.

\section{Conclusāo}

Quando empregamos a palavra "pátio" no termo "rua-pátio", estamos fazendo, de certa forma, uma alusão ao pátio das antigas vilas, rodeado por edificaçōes, recluso no interior do quarteirão e próprio a usos diversos e à sociabilidade.

Evidentemente, pode-se imaginar também que o que se tenta retomar nesses espaços é, na verdade, o uso das antigas ruas (das cidades de outrora), onde pessoas se reuniam para conversar, para observar o movimento e, em ocasiões especiais, até mesmo para fazer refeiçōes comunitárias. Ou seja, a idéia de rua não apenas como espaço público, mas sim como espaço social, lugar de encontro. Dessa forma, talvez não fosse necessário sequer fazer menção ao pátio. No entanto, quando observamos que esse trecho de rua, ladeado por casas, está encerrado no condomínio, entre seus muros e portões, percebemos que, apesar de sua linearidade, há nesse espaço determinadas características de pátio - ao menos do pátio das antigas vilas, embora não se situe em áreas mais internas à quadra (aparece agora no centro do conjunto, cujo lote possui pelo menos uma de suas faces voltada para a rua principal).

Nas novas vilas que ocupam quadras inteiras, com um número maior de residências Igeminadas e produzidas em sériel e mais de uma rua interna, essa característica de pátio parece desaparecer. Aí sim, prevaleça talvez a idéia de rua (e não de pátio) como espaço social. O que se tem, então, são ruas protegidas por grades e muros, que possibilitam outros usos.

Há casos, ainda, em que o pátio propriamente dito se faz presente. No Condomínio Franz Schubert, por exemplo, a rua, com cerca de $8 \mathrm{~m}$, alarga-se conformando um pátio onde está instalado um salāo de festas. No entanto, ao que parece (de acordo com o que temos constatado), essa forma de distribuição espacial não tem sido muito comum nas novas vilas. São mais usuais a "rua-pátio" ladeada por unidades residenciais e, nos conjuntos maiores, que ocupam quadras inteiras, duas ou três ruas internas.

A vantagem do pátio propriamente dito, depois da rua estreita ou um pouco mais larga, seria garantir uma privacidade maior aos seus usuários - quando existissem portões que possibilitassem a visualização dos espaços internos -, e dar lugar ao "elemento surpresa", uma vez que haveria cantos e recantos que permaneceriam ocultos até que se chegassse perto deles. 


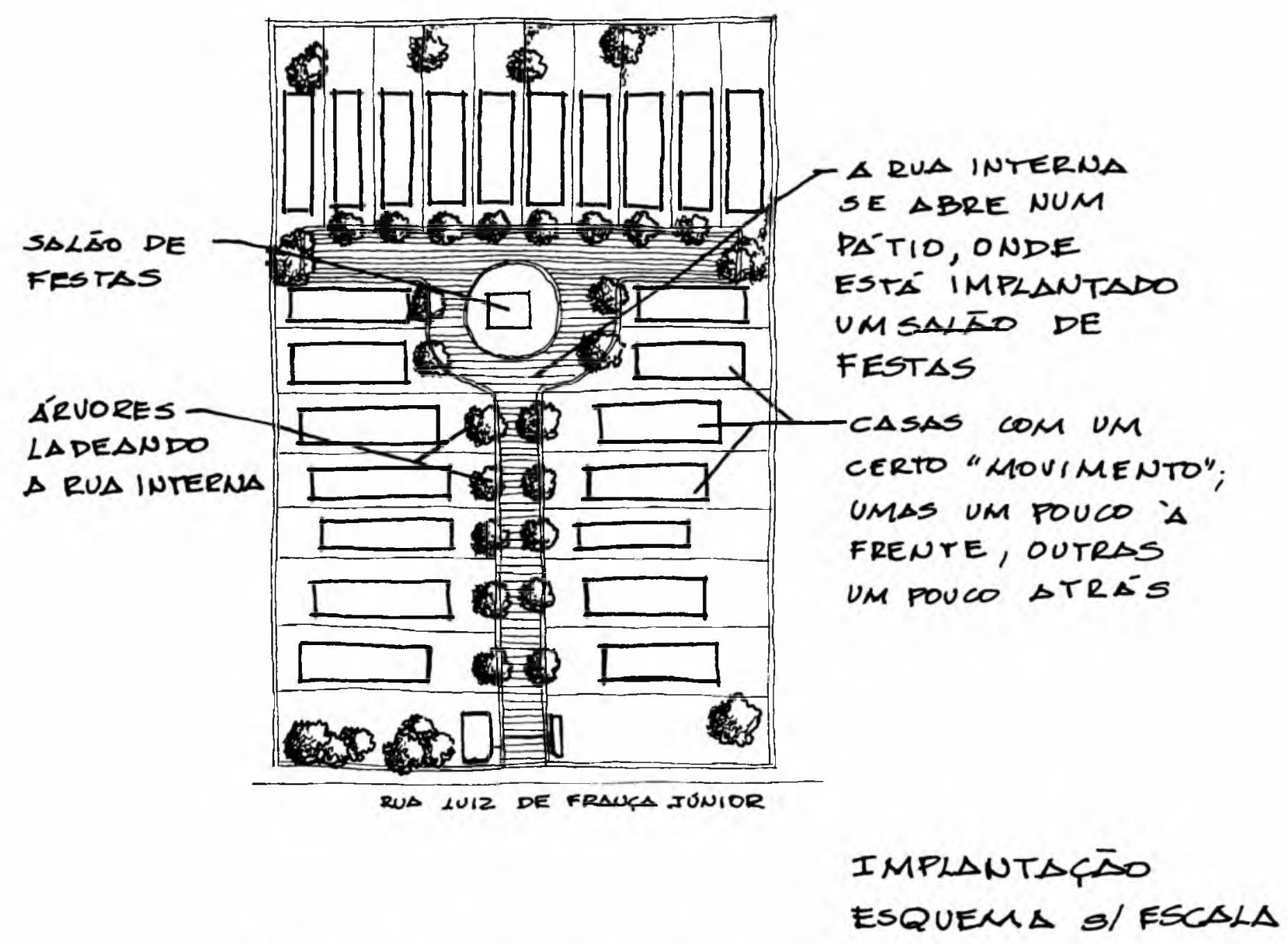

Figura 29: Franz Schubert. A rua se abre num pátio (Implantação esquemática) Fonte: Autora

Em boa parte dos novos conjuntos, no entanto, como pudemos ver, o pátio e a rua estreita deram lugar a um espaço único, cujas características são determinadas pela forma de implantação das residências, pela topografia, pelas dimensões do terreno, pelo estilo arquitetônico adotado e pelo projeto paisagístico. Assim, a estruturação dos espaços livres das novas vilas de classe média difere daquela encontrada nos antigos conjuntos, como difere também o cenário, embora na "vila-condomínio fechado" tente-se resgatar ou trazer para o presente características, elementos e usos da vila isolada da cidade pela rua estreita (passagem obrigatória para a descoberta do conjunto e do pátio).

(*) Observação: Os desenhos de implantação foram feitos a partir da observação dos respectivos catálogos imobiliários, tendo sido simplificados ou acrescidos de alguns detalhes.

\section{Paisagem} São Paulo n. 13 p. 201229 - dez. 2000 


\section{Bibliografia}

AN INTRODUCTION TO HOUSING LAYOUT. Nova York: Nichols Publishing Company, 1978.

ARAGÃO, Solange. Da persistência do ecletismo nas vilas paulistanas. São Paulo, 2000. Dissertação (Mestrado) Faculdade de Arquitetura e Urbanismo, Universidade de São Paulo.

HERTZBERGER, Herman. Liçōes de arquitetura. Tradução de Carlos Eduardo Lima Machado. São Paulo: Martins Fontes, 1996.

MACEDO, Silvio Soares. Espaços livres. Paisagem e ambiente, São Paulo: FAUUSP, n.7, p. 15-56, 1995.

MARX, Murillo. Cidade brasileira. São Paulo: Melhoramentos - Edusp, 1980.

Cidade no Brasil. Em que termos7 São Paulo: Studio Nobel, 1999.

REIS FILHO, Nestor Goulart. Quadro da arquitetura no Brasil. São Paulo: Perspectiva, 1970. 